\title{
Calcerous Tufa as Invaluable Geotopes Endangered by (Over-)Tourism: A Case Study in the UNESCO Global Geopark Swabian Alb, Germany
}

\author{
Heidi Elisabeth Megerle
}

check for updates

Citation: Megerle, H.E. Calcerous Tufa as Invaluable Geotopes Endangered by (Over-)Tourism: A Case Study in the UNESCO Global Geopark Swabian Alb, Germany. Geosciences 2021, 11, 198. https:// doi.org/10.3390/geosciences11050198

Academic Editors:

Jesus Martinez-Frias and Maria Górska-Zabielska

Received: 30 March 2021

Accepted: 30 April 2021

Published: 2 May 2021

Publisher's Note: MDPI stays neutral with regard to jurisdictional claims in published maps and institutional affiliations.
University of Applied Forest Sciences Rottenburg, Schadenweilerhof, D-72108 Rottenburg am Neckar, Baden-Wuerttemberg, Germany; megerle@hs-rottenburg.de; Tel.: +49-7472-951-243

\begin{abstract}
Calcerous tufa and sinter are among the most impressive natural spectacles in karst landscapes whose scientific and aesthetic value is universally recognized. Being visually often very appealing they attract numerous visitors. At the same time tufa landforms are extremely vulnerable and can be seriously damaged even by minor interference. The challenge is, therefore, to protect the calcerous tufa heritage, to communicate its values, and to enhance it with the help of adequate geotourism offers. Tufa geotopes are an essential part of the geological heritage of the UNESCO Global Geopark Swabian Alb in Southwest Germany. Unfortunately tufa landforms, especially tufa cascades, suffer serious impairments by (over-)tourism, particularly during the Corona pandemic. The article explores where best to strike the balance between valorization and protection, as well as how to ensure that growth in tourism is compatible with nature preservation, especially in the case of the extremely vulnerable tufa geotopes.
\end{abstract}

Keywords: calcerous tufa; geotourism; geoheritage; geotope protection; UNESCO Global Geopark Swabian Alb; (over-)tourism; corona-pandemic

\section{Introduction}

Geotourism, long considered a form of niche tourism [1], has recently become a popular form of themed tourism [2-8]. Over the course of the past decade, geotourism has been one of the fastest growing branches of tourism [9]. Geotourism concentrates not only on geology, but also focuses on a broad spectrum of topics related to the history of the earth and landscapes, including vegetation, fauna, cultural landscapes, and anthropogenic features, such as mines and quarries. Geotourism can make a valuable contribution to sustainable regional development. At the same time, it is important to raise public awareness of the importance of geotopes and their protection [8].

Since the mid-1990s, geotourism has developed dynamically, and there has been much academic debate as to its precise definition and how best to manage geoheritage $[2-8,10]$.

The assets of geoparks span a wide spectrum of geological and geomorphological landforms, ranging from active volcanism to Precambrian rock formations. Karst landscapes are popular tourist destinations worldwide. Tropical karst (i.e., karst cones and towers, e.g., in China and Vietnam, including Halong Bay) in particular attracts numerous visitors. Caves are the most visited geotouristic features across the globe [11-14]. There are karst features in at least one third of all geoparks. These include numerous geoparks in Germany, as well as elsewhere in Europe.

Calcerous tufa and sinter are among the most impressive natural spectacles in karst landscapes whose scientific and aesthetic value is universally recognized [15-25]. Some are therefore designated as UNESCO World Heritage Sites, such as the Plitvice Lakes in Croatia [26].

Tufa formations can be visually very appealing and thus attract numerous visitors. About 1.3-1.5 million tourists visit the Plitvice Lakes [27], rising annually by over one 
percent on average [26]. Jiuzhaigou National Nature Reserve and the scenic and historic region of Huanglong are popular tourist destinations in China. The number of tourists in Jiuzhaigou has increased from 27,000 in 1984 to 5.1 million in 2015, which represents a 188-fold increase [28]. In the light of the negative impact of such tourist crowds on the environment, this explosion of visitor numbers may be classified as 'overtourism' [29]. It is worth noting here that tufa landforms are extremely vulnerable and can be seriously damaged even by minor interference. In recent years, numerous authors have addressed the problem of the increasing endangerment of the geo-heritage [2-8,10,30-38].

This article focuses on the special characteristics of tufa formations, as well as on their great importance as geotopes, biotopes and tourist attractions. Furthermore, we will discuss the various risk factors. Based on the case study of the UNESCO Global Geopark Swabian Alb (Figure 1), we will explore where best to strike the balance between valorization and protection and offer possible solutions. Current developments in the context of the Corona pandemic form a special focus of our study. While restrictions on travel and the use of recreational facilities have led to a significant decline in the number of international tourists [39], there has been a simultaneous rediscovery of the "Heimat" (homeland), associated with a significant increase in visitors to natural areas, the latter mostly with negative repercussions for the environment [40].

\section{Materials and Methods}

Our study consists of a general overview of tufa landforms and the possible influence by tourism, followed by a detailed case study in UNESCO Global Geopark Swabian Alb, Schelklingen, Germany.

\subsection{Tufa Inventory}

The general overview is based on an extensive literature research. For the federal state of Baden-Württemberg comprehensive mappings of geotopes [41,42], as well as biotopes [43] are the basis of our survey. As tufa cascades have a high ecological value they are included in the mapping of biotopes worthy of protection [43]. In 2017, a management concept for outstanding geotopes within the Geopark was published [44]. We verified the mapping by own surveys in the field.

\subsection{Evaluation of Tufa Landforms Endangerments}

The general overview again is based on literature research. All 17 national geoparks in Germany received a questionnaire on possible tufa landforms, their endangerment and protective measures. For our case study the management concept [44] was used as a basis. For the recorded geotopes, the degree of impairment is indicated in three levels (no, low, strong impairment). As effects of the actual corona pandemic are not included we checked all the geotopes described by own surveys in the field. Hereby we paid particular attention to visible impairments, the sensitivity of the respective geotope and the number of visitors.

In addition interviews with experts were included and many years of first-hand experience as a scientist, landscape guide and vice chairwoman of the advisory board of the UNESCO Geopark Swabian Alb.

\subsection{Study Area}

The Swabian Alb is a low mountain range in Southwest Germany, which stretches over a length of $220 \mathrm{~km}$ from the Upper Rhine in the Southwest to the border of the Nördlinger Ries in the Northeast and thus covers an area of approximately $5800 \mathrm{~km}^{2}$ (see Figure 1). The Swabian Alb is part of the Southwest German cuesta landscape. Lower (Lias) and middle (Dogger) Jurassic sediments shape the foothills, while Upper Jurassic sediments (Malm) form the striking cuesta, rising up to $400 \mathrm{~m}$ in height over the surrounding landscape. The flat South-east facing plateau of the Jura, due to the prevailing limestone, represents the largest karst region in Central Europe and is characterized by diverse karst forms like caves, tufa cascades, and sinkholes. With 2400 recorded caves, including 12 show caves 
attracting annually over 320,000 visitors, there is no region in Germany with a higher number and concentration of caves. There are also numerous sinkholes, hunger wells, dry valleys, etc. [45]. A special feature are the forms of tertiary volcanism, which are concentrated in the Urach-Kirchheim area, and form one of the largest volcanic vent fields on earth [46].

Southwest Germany is of global importance for geologists, boasting two meteor craters (Nördlinger Ries and Steinheimer Becken) and world-famous fossil sites (e.g., Holzmaden). It is also well known for Friedrich-August von Quenstedt's research of Jurassic stratigraphy and Albrecht Penck's exploration of the Ice Ages, for being home to the archaeological sites where homo heidelbergensis and steinheimensis have been found and for the UNESCO World Heritage Site 'Caves and Ice Age Art in the Swabian Jura'. (For further information on the geology of the Swabian Alb, see [47,48]).

The Swabian Alb Geopark was established in 2000. In 2002, it was granted the status as a National and European Geopark; in 2015 as UNESCO Global Geopark. The Geopark encompasses virtually the entire Swabian Alb (Figure 1). 


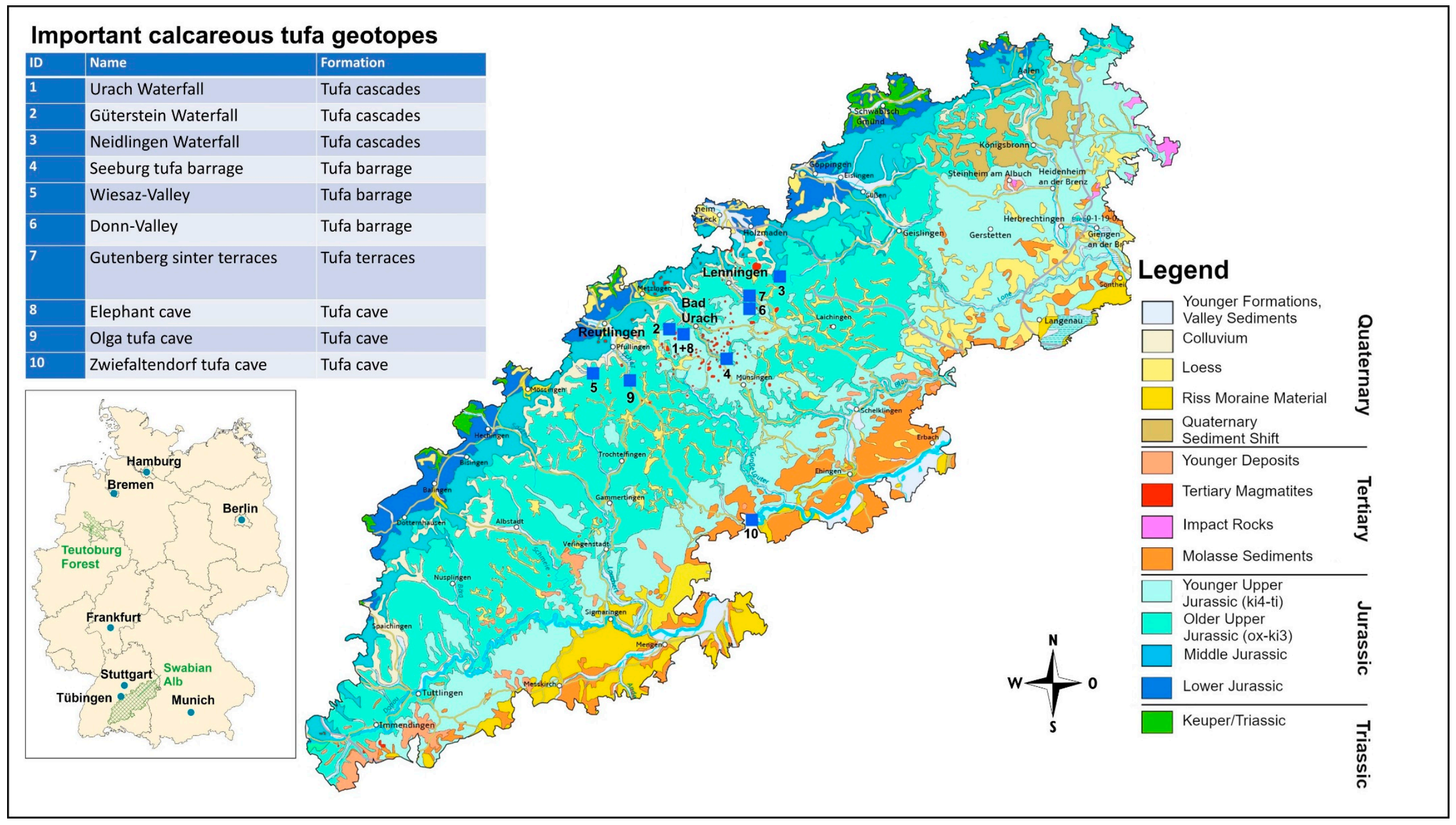

Figure 1. Geological map of the UNESCO Global Geopark Swabian Alb, Germany, with the location of the most relevant tufa landforms (Author's design). 


\section{Tufa Geotopes}

There are various tufa formations of different origins. The degree of the danger they face and the ways they can be made accessible to tourists differ markedly from case to case.

\subsection{Tufa Formations}

Tufa forms in regions with limestone deposits that are soluble and exhibit strong fissuring [49,50]. Calcium carbonate changes into calcium hydrogen carbonate under the influence of carbonic acid-saturated water [51]. Near-surface karstification is mainly dependent on the water supply and the water's capacity to absorb $\mathrm{CO}_{2}$, which increases with decreasing temperature. At spring outlets, temperature and pressure conditions change, so that $\mathrm{CO}_{2}$ escapes and at least some dissolved lime falls out and a deposit of tufa builds up. The larger the surface, the higher the escape rate of $\mathrm{CO}_{2}$. As a result, extensive tufa deposits form at waterfalls [52]. Specialized types of moss and algae increase tufa precipitation as they remove $\mathrm{CO}_{2}$ from the water for their assimilation (Figure 2).

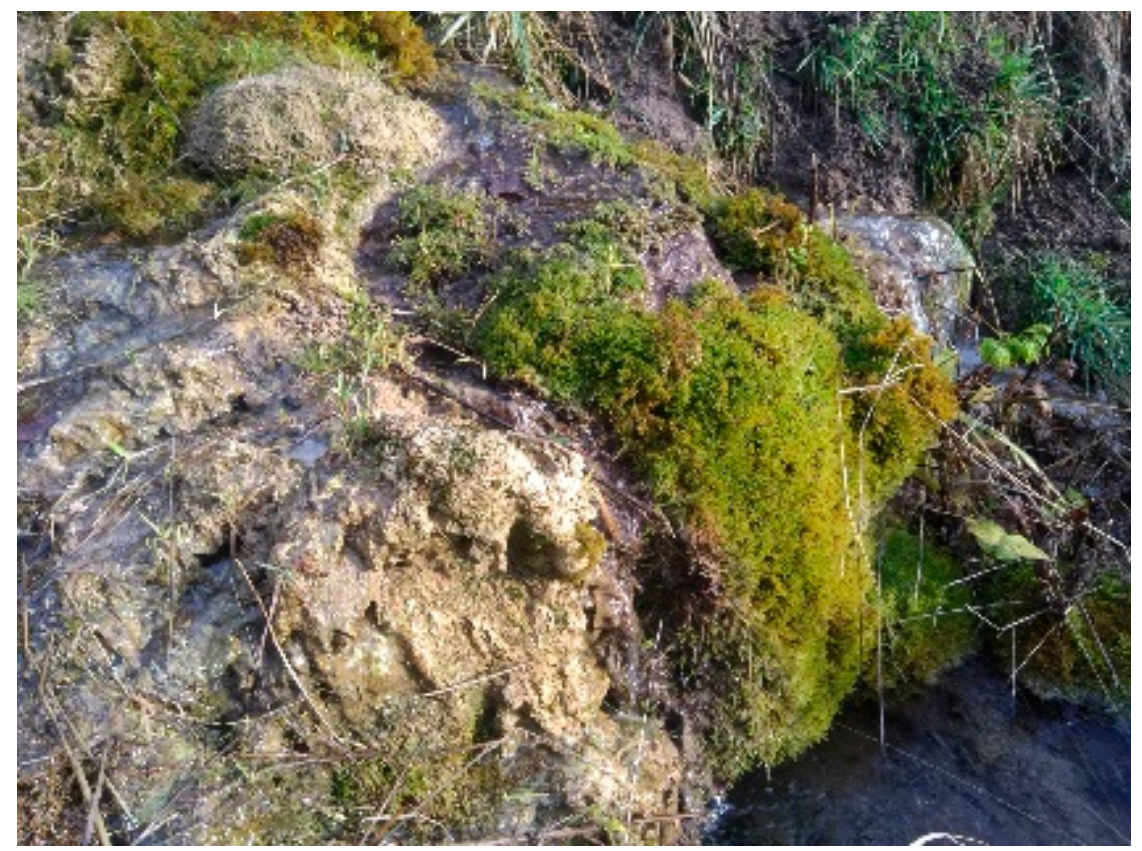

Figure 2. Small tufa cascades in the UNESCO Global Geopark Swabian Alb, Germany.

Tufa refers to a mostly loose, non-stratified and partly non-consolidated rock at nonthermal freshwater springs, often with plant inclusions and numerous cavities. In contrast to this, travertine deposits in more mineralized or low temperature thermal waters, and sinter form at thermal springs [53]. In contrast to calcareous tufa, travertines, and sinter are dense, solid rocks. The transitions between calcareous tufa and travertine are, however, fluid $[50,54]$. The natural stone industry appreciates the distinct qualities of travertine and tufa, and this is reflected in different processing techniques. Travertine is fine-grained and can be grounded and polished. Calcareous tufa is easy to extract and hardens when exposed to the air [55]. The name 'tufa' is due to its loose, porous structure, which is reminiscent of volcanic tuffs. Calcareous tufa is, however, not of volcanic origins. One finds this porous limestone in tufa cascades, tufa barrages and natural caves. Tufa is widespread across the globe $[54,56]$ have compiled a detailed account of the world's tufa and travertine deposits.

Tufa cascades are widespread in Europe, with the exception of Portugal, the Pannonian region from Slovenia to Romania and the steppe zone. In Germany, tufa cascades are located mainly in the limestone areas of low mountain ranges and in the foothills of the Alps, but also in the North German lowlands. Particularly well developed forms are located in Southern Germany, including the UNESCO Global Geopark Swabian Alb (see 
Section 4.1) [43]. Due to the small area covered by calcareous tufa formations and the minor importance attributed to them, they are not even mentioned in most overviews, e.g., on the geology [57] or the physical geography of Germany [58]. [56] state that there are numerous tufa formations in Germany. Most of the literature, however, tends to be local and not easy to access for non-specialists, so that such formations are not widely known.

At tufa cascades, one frequently finds smaller and larger waterfalls with 'tufa noses'. Larger waterfalls, however, usually do not occur naturally, but are deliberately created, for example, as a tourist attraction (see Section 4.2). Other typical limestone tuff formations are braided channels. Tufa cascades have a high ecological value, as they form habitats for rare animal and plant species. In the context of climate change, tufa is currently gaining new importance [50,59], as it is considered an excellent indicator of past climate conditions [60].

Primary caves develop frequently within tufa cascades [47]. Depending on the exact conditions of formation, three types are distinguished: the valley, slope, and waterfall types [61].

Tufa barrages form in flowing waters in the area of obstacles (e.g., branches, etc.). Water-filled basins may develop behind such natural dams (Figure 3). At Plitvice, this process has created a sequence of terraces and lakes [50]. [52] differentiates between thick tufa barrages, formed in in the past in larger valleys, and small tufa barrages in creeks, where tufa formation is still active today.

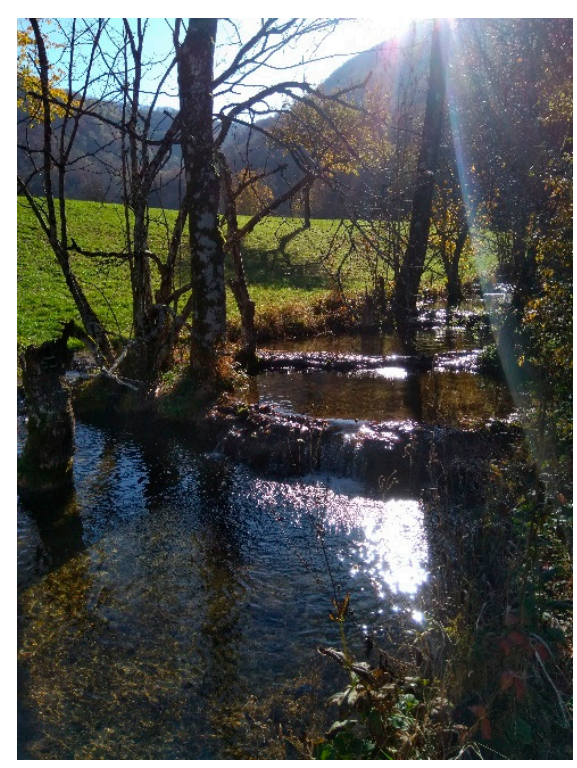

Figure 3. Sinter basins in Donn-Valley (No. 6 in Figure 1) in UNESCO Global Geopark Swabian Alb, Germany.

Despite their usually small size, tufa and sinter often form spectacular natural sights $[15,49]$. This makes them attractive destinations for geotourism.

\subsection{Endangerment of Tufa Geotopes}

Tufa geotopes are in great danger by a series of factors (listed below). However, this mainly concerns the tufa cascades. Tufa barrages are usually very compact and, therefore, less vulnerable. They are also less frequently visited by tourists and are nowadays usually no longer used for the extraction of building stones. Access to primary caves is usually regulated and monitored, which makes them also less vulnerable.

Size: Tufa cascades are often very small geotopes, lacking a buffer zone (see Figure 2).

Fragility: Calcerous tufa is mostly a very loose and porous rock due to its formation processes. Therefore, even minor human interference, such as trampling, can cause considerable damage (see Figure 4). 


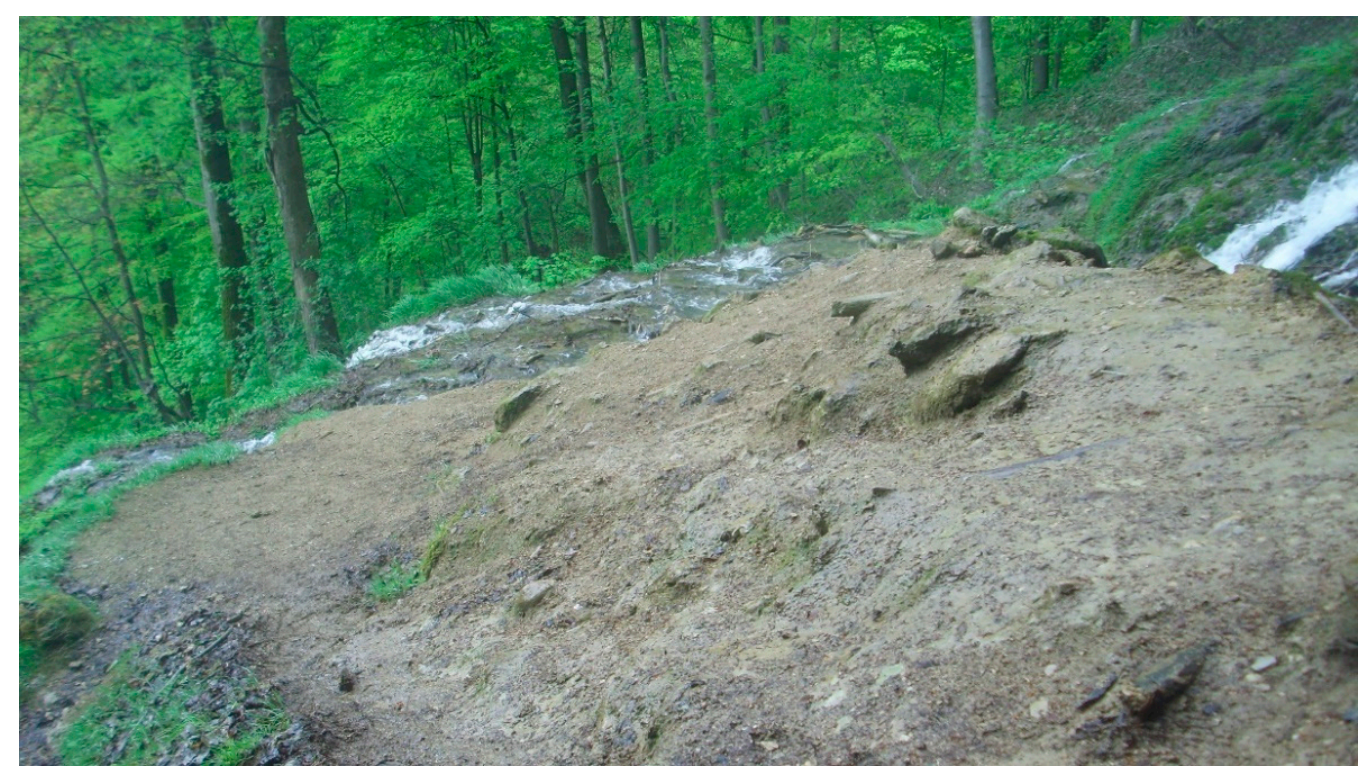

Figure 4. Trampling damage at Urach Waterfall (No. 1 in Figure 1) in UNESCO Global Geopark Swabian Alb, Germany.

Tourism: Tufa formations are often very attractive (see Figure 5) or form water pools that are used for bathing (see Figure 3). These landforms are often popular tourist destinations and are, therefore, under an increasing threat from the rapid expansion of tourism [17]. Since tufa formations are very sensitive to external influences (see above), even relatively small numbers of visitors can cause considerable damage, especially if they do not behave appropriately. Footpath erosion destroys first vegetation and soil cover and ultimately leads to erosion and the formation of gullies [62]. The input of nutrients [53] and garbage also have a harmful impact. As a result of these side effects of tourism, there are numerous cases of tufa landscapes suffering serious degradation [5,15-17,63-68], ( see for example. the case studies of the Urach waterfall and the Donn-Valley). At many destinations, such developments resulting from over-tourism [54] have been recorded.

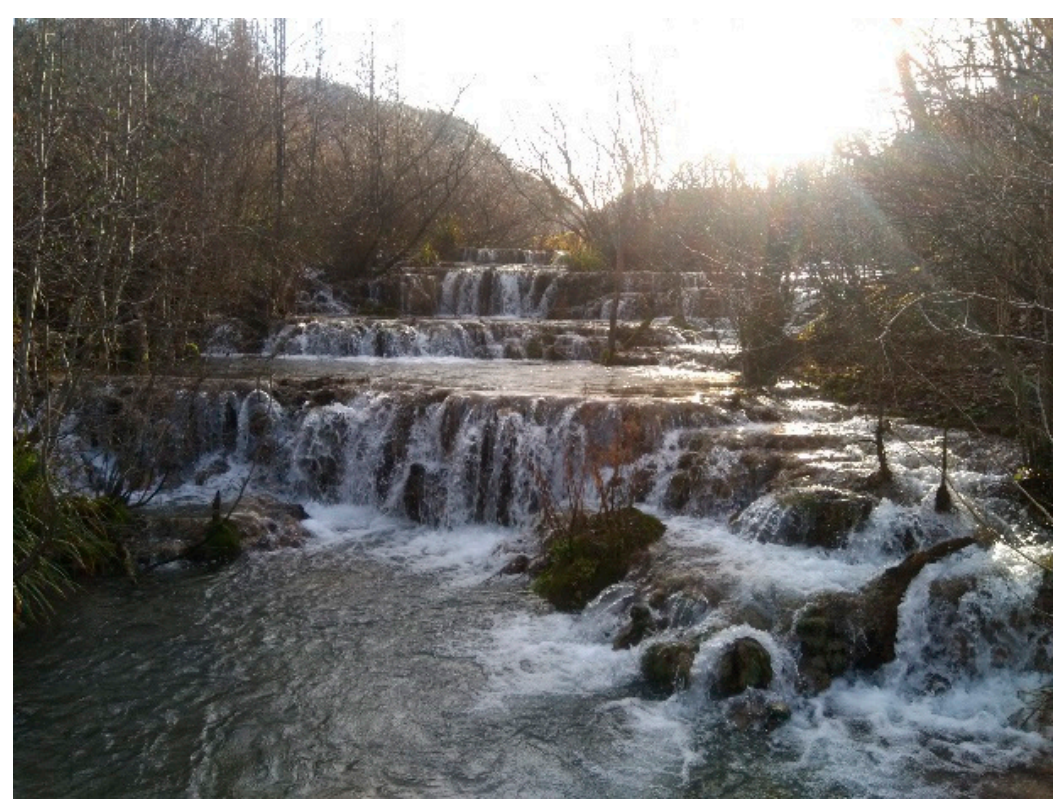

Figure 5. Sinter terraces in Gutenberg (No. 7 in Figure 1) in UNESCO Global Geopark Swabian Alb, Germany. 
At the Skradinsik Buk Waterfall in the Krka National Park (Croatia) the number of visitors is restricted to 10,000 persons at a time due to concerns over safety and potential damage to the landscape [50]. In Plitvice National Park the degradation of the tufa landscape, due to uncontrolled tourism, has reached such a serious level that its possible exclusion from the list of UNESCO World Heritage Site has been considered [69].

Even the less vulnerable sinter terraces suffer greatly from too many visitors (Figure 6) [42]. Therefore, it should be a priority for tourism to preserve the geosites, respecting the natural environment and cultural context and to apply the principles of sustainability [70-72].

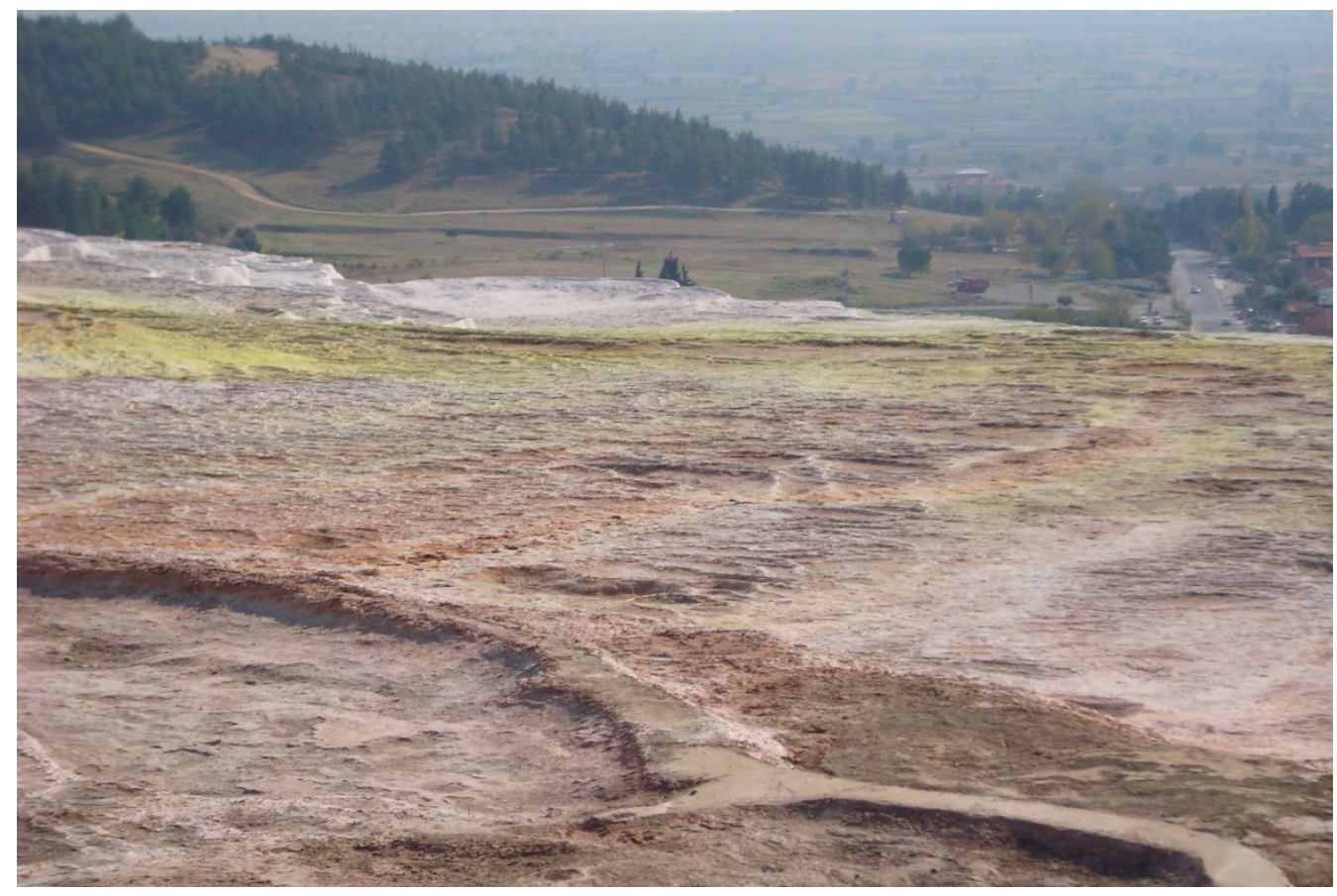

Figure 6. Damaged sinter terraces in Pamukkale, Turkey.

Nutrient and pollutant input: Calcareous tufa is relatively nutrient-poor by nature. Nutrient and pollutant input by visitors or agriculture endangers plant communities. This is not only a considerable threat to the biotope type 'Cratoneurion', but also to the geotope, since the plants, through their assimilation, contribute decisively to the precipitation of calcareous tufa and to the formation of the typical terraces. Nutrient accumulation promotes excessive diatom growth, which contributes to a loose tufa deposit structure. The stability and erosion resistance of tufa deposits are weakened as a result of this [53]. Even vegetation-free sinter terraces, however, can be seriously threatened by pollutants (Figure 6).

Alteration of water supply: Any form of alteration of the water supply endangers the formation of calcareous tufa. This may be due to a smaller amount of water, e.g., through drainage measures in the inflow area or a complete cut-off by installing spring taps, cattle troughs, and piping [43].

Invasive species: The uncontrolled spread of invasive species, such as Ailanthus altissima, can have significant negative impacts on the tufa formation [15]. This also applies to green algae [16].

Stone industry: In the mountain-moist state, calcerous tufa is easy to work, in the dry state it is very stable and has good insulating properties, due to its high porosity. For this reason in Southern Germany, it was a sought-after building material for stables, where precisely these insulating properties were appreciated. It has also been used for representative monuments, such as the portal of the castle at Tübingen (Figure 7). Tufa 
sand, formed through abrasion of the calcerous tufa, has also been of some economic importance [73].

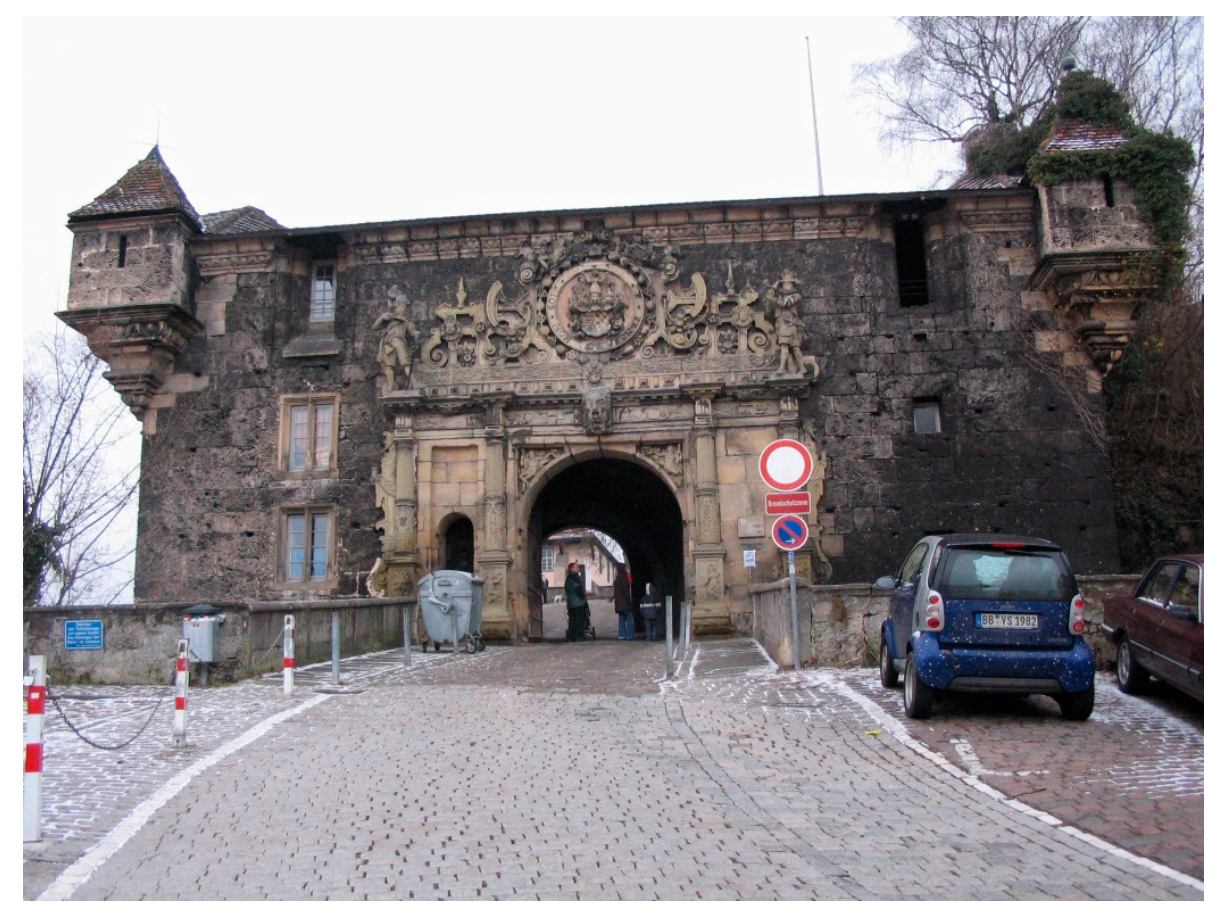

Figure 7. Castle portal in Tübingen built with calcerous tufa from UNESCO Global Geopark Swabian Alb, Germany.

The Romans already quarried tufa near Badenweiler (Baden-Württemberg) [55] and on the Swabian Alb near Geislingen. At the Roman fort of Heidenheim, numerous tufa blocks were unearthed [74]. Especially in the 19th and at the beginning of the 20th century, tufa was quarried on a large scale as a popular building material. In Baden-Württemberg, a total of 63 quarries could be recorded, although in many places quarrying lasted only for a short period of time. Today tufa exploitation is largely banned in Germany, with only two small quarries still operational in Baden-Württemberg [55].

\subsection{Legal Protection of Tufa Formations}

In Germany, natural caves are automatically protected by federal law. Show caves are excluded but, being only accessible within the framework of guided tours, so far do not appear to have suffered any serious damage.

Tufa-forming hard water springs are classified as a priority natural habitat of community interest and are listed in Annex I of Community Directive 92/43/EEC as "(Natura, 2000 habitat type $7220^{*}$ Petrifying springs with tufa formation (Cratoneurion) $)^{\prime \prime}$. In Germany, tufa-forming springs are also protected by federal law and in Baden-Württemberg by state law. This legal protection, however, refers to the natural habitat, not to the geotope. Protection of geotopes is generally still a stepchild of nature conservation in Germany [75].

Since all tufa forming springs are in principle protected by law, ref. [43] classifies the conservation conditions as "favorable" and sees no requirement for maintenance and management. Unfortunately, listing as an FFH habitat type, designation as a nature reserve or other forms of legal protection is not always sufficient $[62,63]$ (see Section 4.3).

\subsection{Geoparks and Geotouristic Valorization of Calcareous Tufa}

In June 2000, the network of European Geoparks was launched. Geoparks are no large-scale protected areas, but are regions rated as having outstanding geopotential, and they must have a strategy for sustainable regional development [76]. In 2002, Germany introduced a rating for National Geoparks [77]. At the end of 2015, the UNESCO launched 
Global Geoparks as a further category of UNESCO sites-in addition to World Cultural Heritage, World Natural Heritage, and Biosphere Reserves [78].

Geoparks should develop sustainable geotourism and, as innovation regions, reconcile comprehensive protection with economic development [79]. In 2011, the European Geoparks adopted the Arouca Declaration, which defines the framework of the desired sustainable geotourism activities, including measures for geotope protection and geoeducation [76].

There are currently 17 National Geoparks in Germany, six of which are also European and UNESCO Global Geoparks. Calcareous tufa is only relevant in a few German geoparks. Either because of the regional geology there is no tufa (e.g., Geoparks Vogelsberg, Porphyrland, Grenzwelten Geopark, and Ruhrgebiet Geopark) or there are merely small localized phenomena (Geopark Vulkaneifel). In addition to the Swabian Alb Geopark (Section 3), only the Teutoburg Forest Geopark has relevant tufa landforms. The waterfall Dreimühlen (Geopark Vulkaneifel) is the only German National Geotope being a tufa formation.

Germany does not have large-scale and internationally known tufa landforms, such as the Plitvice Lakes. The local calcareous tufa landforms are usually rather small, like the sinter terraces near Dissen [80] covering only $0.13 \mathrm{ha}$, but they are nevertheless the largest sinter deposit in Lower Saxony. Still calcareous tufa formations can play a very important role in geotourism and value creation on a local and on a regional level. The sinter terraces near Dissen are one of the most important highlights in the Geopark Teutoburg Forest [80], as is the Urach waterfall in the Geopark Swabian Alb (see Section 3.2).

The statement by [81] that geotourism normally has little or no effect on the integrated geopotentials, unfortunately, mostly does not apply to tufa formations. Tufa formations are very vulnerable (see Section 2.2) and are in many cases already endangered [15,63]. Thus, a well-founded assessment of opportunities and risks must be carried out before geotouristic valorization. Numerous methods for the quantitative assessment of geoheritage are presented in international literature [14,70,82-86], especially for karst geotopes [87]. Furthermore, it is necessary to continuously monitor the visitors' impact, to adapt the limits of carrying capacity and thus determine the maximum number of visitors. This is the only way to minimize the negative impacts of tourism, while taking advantage of all its positive impacts [26].

\section{Case Study: UNESCO Global Geopark Swabian Alb, Germany}

The UNESCO Global Geopark Swabian Alb in Southwest Germany was chosen as a case study area.

\subsection{Tufa Formations within the Geopark Swabian Alb}

The Alb's natural conditions, with high levels of precipitation (on average 800 to $1000 \mathrm{~mm}$ /year) and low annual mean temperatures $\left(4^{\circ} \mathrm{C}\right.$ to $\left.7{ }^{\circ} \mathrm{C}\right)$, favor karstification. The mighty tufa deposits originated mainly in the postglacial warm period [88], but tufa formation has continued until today. The statewide mapping of geotopes [41,42] recorded 29 high-value tufa geotopes within the area of the geopark, including 21 tufa cascades, some with waterfalls, four primary tufa caves, two tufa barrages, and two former tufa quarries. Of these geotopes, 21 are protected and the other eight are worthy of protection. These numbers do not include geotopes that are not thought to merit protection.

Below, the Geopark's tufa landforms are described in general, with a particular emphasis on outstanding examples. Table 1 lists specific protection categories and the degree of endangerment. Section 4.3 goes into more detail about negative impacts caused by tourism. 
Table 1. Important tufa landforms within the UNESCO Global Geopark Swabian Alb, Germany.

\begin{tabular}{|c|c|c|c|c|c|c|c|}
\hline Name & $\begin{array}{l}\text { Geographical } \\
\text { Position }\end{array}$ & $\begin{array}{l}\text { Type of } \\
\text { Geotope }\end{array}$ & $\begin{array}{l}\text { Legal Protection } \\
\text { Status }\end{array}$ & Values & $\begin{array}{l}\text { Touristic } \\
\text { Frequentation }\end{array}$ & Endangerment & $\begin{array}{l}\text { Addition } \\
\text { Remarks }\end{array}$ \\
\hline $\begin{array}{l}\text { Urach } \\
\text { Waterfall }\end{array}$ & Bad Urach & $\begin{array}{l}\text { Waterfall } \\
\text { Tufa cascades } \\
\text { Primary caves }\end{array}$ & $\begin{array}{l}\text { Nature reserve } \\
\text { Legally protected } \\
\text { Biotop according } \\
\text { \$30 BNatSchG } \\
\text { (federal law) }\end{array}$ & $\begin{array}{l}\text { Scientific } \\
\text { Ecological } \\
\text { Aesthetic } \\
\text { Economic } \\
\text { Cultural }\end{array}$ & $\begin{array}{l}\text { Very high } \\
\text { Extremely high } \\
\text { (Corona) }\end{array}$ & Extremely high & $\begin{array}{l}\text { Section } 4.1 .1 \\
\text { Figure } 1, \\
\text { Figure } 4, \\
\text { Figure } 8 \text { and } \\
\text { Figure } 16\end{array}$ \\
\hline $\begin{array}{l}\text { Güterstein } \\
\text { Waterfall }\end{array}$ & Bad Urach & $\begin{array}{l}\text { Waterfall } \\
\text { Tufa cascades } \\
\text { Primary caves }\end{array}$ & $\begin{array}{l}\text { Nature reserve } \\
\text { Legally protected } \\
\text { Biotop according } \\
\text { \$30 BNatSchG } \\
\text { (federal law) }\end{array}$ & $\begin{array}{l}\text { Scientific } \\
\text { Ecological } \\
\text { Aesthetic } \\
\text { Economic } \\
\text { Cultural }\end{array}$ & Very high & Very high & $\begin{array}{l}\text { Section } 4.1 .1 \\
\text { Figure } 1, \\
\text { Figure } 9 \text { and } \\
\text { Figure } 10\end{array}$ \\
\hline $\begin{array}{l}\text { Neidlingen } \\
\text { Waterfall }\end{array}$ & Neidlingen & $\begin{array}{l}\text { Waterfall } \\
\text { Tufa cascades }\end{array}$ & $\begin{array}{l}\text { Nature reserve } \\
\text { Legally protected } \\
\text { Biotop according } \\
\text { \$30 BNatSchG } \\
\text { (federal law) }\end{array}$ & $\begin{array}{l}\text { Scientific } \\
\text { Ecological } \\
\text { Aesthetic }\end{array}$ & High & High & $\begin{array}{l}\text { Geopoint } \\
\text { Section } 4.1 .1 \\
\text { Figure } 1\end{array}$ \\
\hline Donn Valley & $\begin{array}{l}\text { Lenningen- } \\
\text { Gutenberg }\end{array}$ & $\begin{array}{l}\text { Small tufa } \\
\text { barrages }\end{array}$ & $\begin{array}{l}\text { Nature reserve } \\
\text { Core zone } \\
\text { Biosphere Reserve }\end{array}$ & $\begin{array}{l}\text { Scientific } \\
\text { Ecological } \\
\text { Aesthetic }\end{array}$ & $\begin{array}{l}\text { Low } \\
\text { Very high } \\
\text { (Corona) }\end{array}$ & $\begin{array}{l}\text { Low } \\
\text { Very high } \\
\text { (Corona) }\end{array}$ & $\begin{array}{l}\text { Section } 4.1 .2 \\
\text { Figure } 1 \text { and } \\
\text { Figure } 3\end{array}$ \\
\hline $\begin{array}{l}\text { Sinter terraces } \\
\text { Gutenberg }\end{array}$ & $\begin{array}{l}\text { Lenningen- } \\
\text { Gutenberg }\end{array}$ & Sinter terraces & Nature reserve & $\begin{array}{l}\text { Scientific } \\
\text { Ecological } \\
\text { Aesthetic }\end{array}$ & High & Middle & $\begin{array}{l}\text { Geopoint } \\
\text { Section } 4.1 .2 \\
\text { Figure } 1 \text { and } \\
\text { Figure } 5\end{array}$ \\
\hline $\begin{array}{l}\text { Tufa barrages } \\
\text { Wiesaz-Valley }\end{array}$ & $\begin{array}{l}\text { Reutlingen- } \\
\text { Gönningen }\end{array}$ & $\begin{array}{l}\text { Tufa barrages } \\
\text { Primary caves }\end{array}$ & Nature reserve & $\begin{array}{l}\text { Scientific } \\
\text { Ecological } \\
\text { Aesthetic } \\
\text { Cultural }\end{array}$ & $\begin{array}{l}\text { High (but } \\
\text { mostly bathing } \\
\text { lakes) }\end{array}$ & Low & $\begin{array}{l}\text { Section } 4.1 .2 \\
\text { Figure 1, } \\
\text { Figure } 13 \text { and } \\
\text { Figure } 14\end{array}$ \\
\hline $\begin{array}{l}\text { Tufa barrage } \\
\text { Seeburg }\end{array}$ & $\begin{array}{l}\text { Bad Urach; } \\
\text { Suburb } \\
\text { Seeburg }\end{array}$ & Tufa barrage & No protection & $\begin{array}{l}\text { Scientific } \\
\text { Cultural }\end{array}$ & Very low & $\begin{array}{l}\text { No } \\
\text { Endangerment }\end{array}$ & $\begin{array}{l}\text { Section } 4.1 .2 \\
\text { Figure } 1 \text { and } \\
\text { Figure } 12\end{array}$ \\
\hline Cave Olga & $\begin{array}{l}\text { Lichtenstein- } \\
\text { Honau }\end{array}$ & Primary cave & No protection & $\begin{array}{l}\text { Scientific } \\
\text { Äesthetic } \\
\text { Cultural }\end{array}$ & Low & Low & $\begin{array}{l}\text { Section } 4.1 .3 \\
\text { Figure } 1\end{array}$ \\
\hline $\begin{array}{l}\text { Cave } \\
\text { Zwiefaltendorf }\end{array}$ & Zwiefaltendorf & Primary cave & No protection & Scientific & Low & Low & $\begin{array}{l}\text { Section } 4.1 .3 \\
\text { Figure } 1\end{array}$ \\
\hline
\end{tabular}

\subsubsection{Tufa forming springs}

Ref. [43] lists tufa forming springs as FFH habitat type 7220. In 2012, about 100 ha were recorded in the state of Baden-Württemberg. The Swabian Alb is one of the focal zones. The distribution and total area of those recorded has not changed since a previous survey in 1994. Even if tufa forming springs are in principle protected both as an FFH habitat type, as well as a legally protected biotope, less than half of the tufa forming springs recorded in Baden-Württemberg are located within FFH areas, where their preservation has to be monitored and reported regularly. Tufa forming springs are still active. Tree leaves and other objects deposited therein will still be covered by thin lime deposits within a few years [30].

\section{Urach Waterfall}

The Urach Waterfall is arguably the best-known and most beautiful waterfall and one of the most famous and popular travel destinations on the Swabian Alb [89] (Figures 1 and 8). The water flows over a $150 \mathrm{~m}$ wide tufa block, which integrates two primary caves (Large and Little Elephant Cave) and plunges $32 \mathrm{~m}$ into the depth. Currently, tufa production is estimated at about $5 \mathrm{~m}^{3}$ per year [90]. 


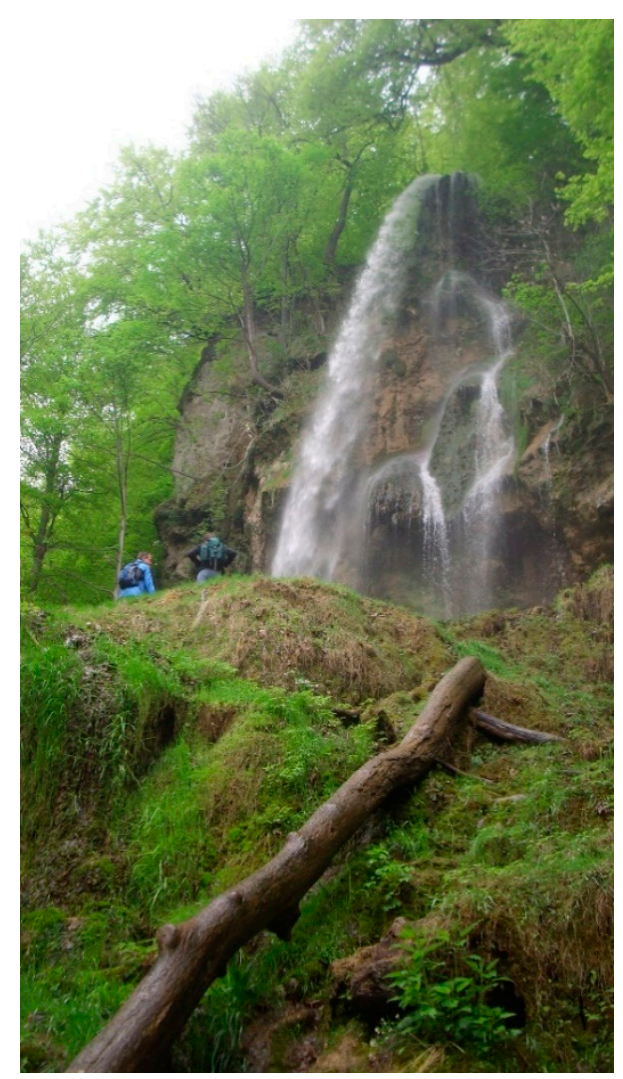

Figure 8. Urach Waterfall (No. 1 in Figure 1) UNESCO Global Geopark Swabian Alb, Germany.

It is largely unknown, that the Urach Waterfall is not natural in its present form. Originally, the Urach waterfall, just like the neighboring Gütersteiner Waterfall (see Figure 9), consisted of a sequence of small tufa cascades over which the water trickled down in a multitude of small watercourses. In the context of extensive exploitation in the 19th century, the tributaries of the former three waterfalls were merged into a single channel, and the highest waterfall of the Swabian Alb was artificially created in the form it still exists today [90]. The motivation for this intervention was already at the time to attract tourists to the Alb. Today, the Urach Waterfall is much promoted as one of the Geopark's geological highlights [44].

\section{Gütersteiner Waterfall}

The Gütersteiner Waterfall is located approximately $2 \mathrm{~km}$ to the northwest of the Urach Waterfall and is similar in terms of geological origins (see Figures 1 and 9). With an annual increase of up to $3 \mathrm{~cm}$, this waterfall has one of the fastest recent tufa formation rates [52]. Tufa mining strongly modified the Gütersteiner Waterfall. This is still clearly visible in the terrain today (see Figure 10), and the basin that was created for water supply is a prominent landscape feature. Exploitation also reduced the large tufa terraces in size. Later the terraces were redesigned. The water is channeled to the site and falls over three steps, each about six meters in height, into the valley, forming the typical tufa noses and tufa cushions [42]. 


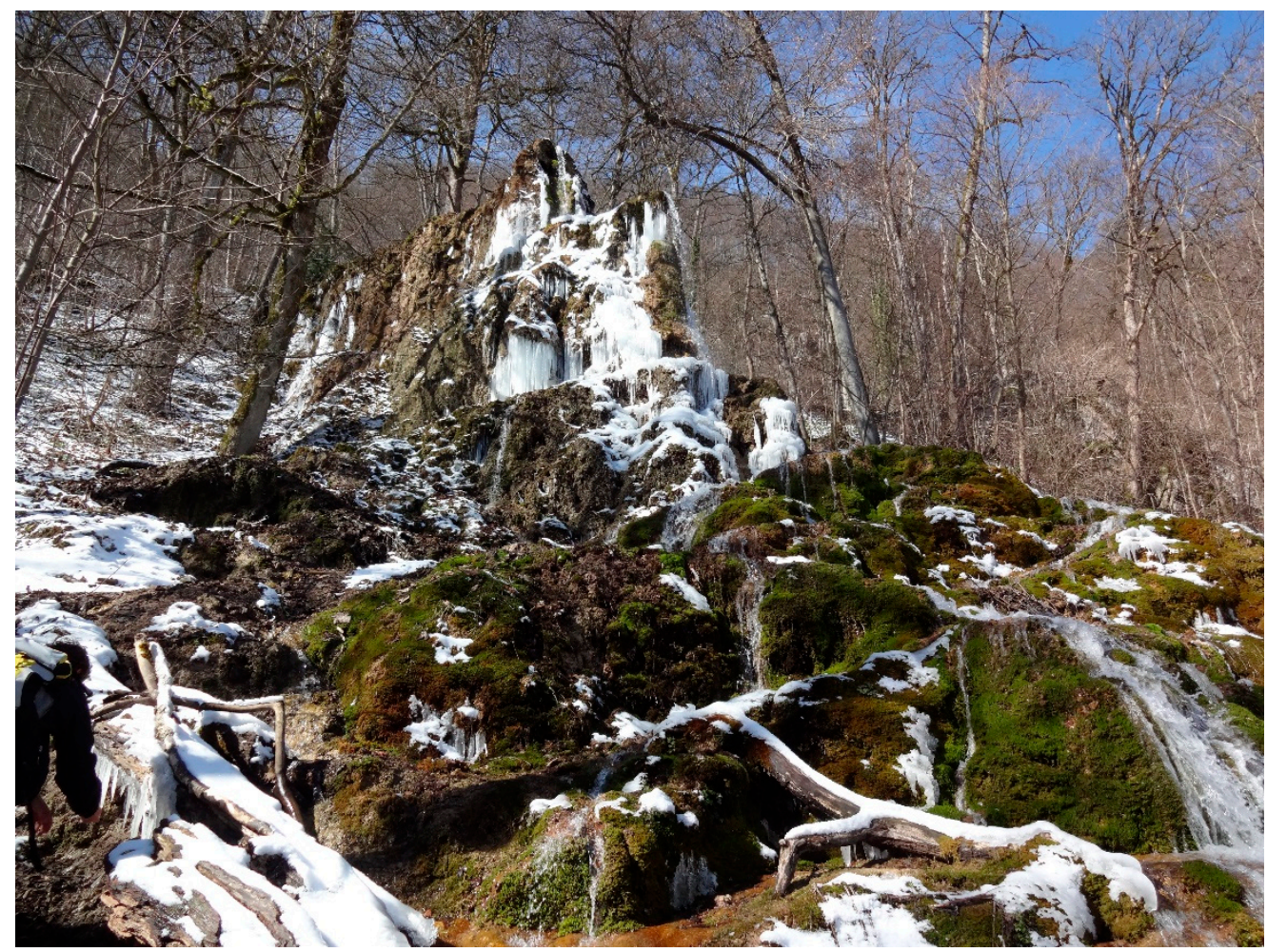

Figure 9. Güterstein Waterfall (No. 2 in Figure 1) UNESCO Global Geopark Swabian Alb, Germany. (Till Langrehr 2013).

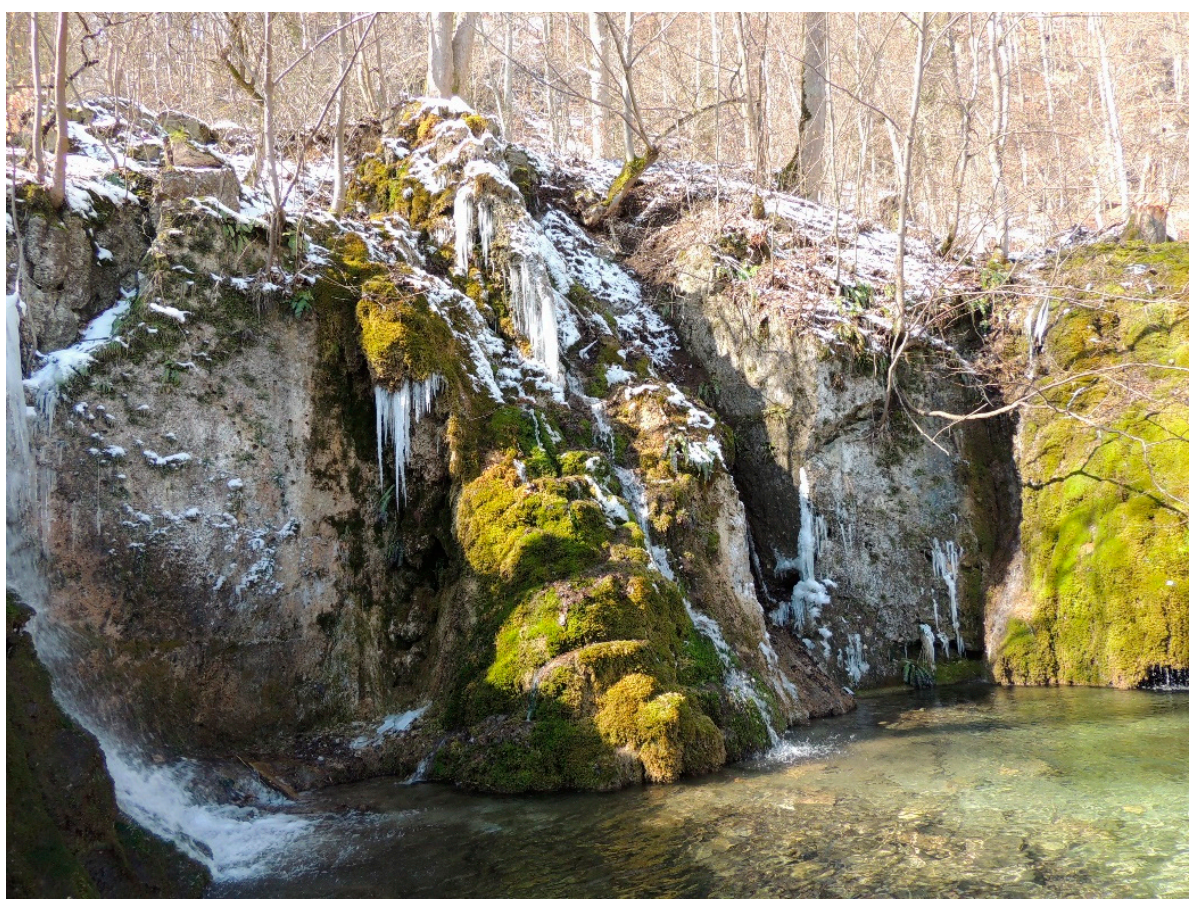

Figure 10. Traces of exploitation at Güterstein Waterfall (No. 2 in Figure 1) UNESCO Global Geopark Swabian Alb, Germany.

In addition to the Urach Waterfall, several primary caves are also found here, the largest of which, the Güterstein Charterhouse, was used from 1226 to 1534 as the burial place of the dukes of Württemberg [89]. At that time, the Güterstein monastery, which had been politically very influential for centuries, was located on the uppermost tufa terrace. When Württemberg became protestant in the course of the Reformation, the 
burial place was moved to Tübingen and the monastery was abandoned [91]. Residents of the surrounding areas used the ruins of the monastery as a quarry for building material, completely erasing the monument. Today, there are no material traces left of the waterfall's earlier cultural significance.

Almost every hiking guide, tourist brochure or other popular scientific publication about the Swabian Alb features the waterfalls. The Urach Waterfall is one of the most popular destinations in the Swabian Alb and attracts up to half a million visitors per year. Especially on holiday weekends, the waterfall and the access roads tend to become overcrowded (Figure 11). The Güterstein Waterfall has slightly fewer visitors than the better-known and visually more spectacular Urach Waterfall [92].

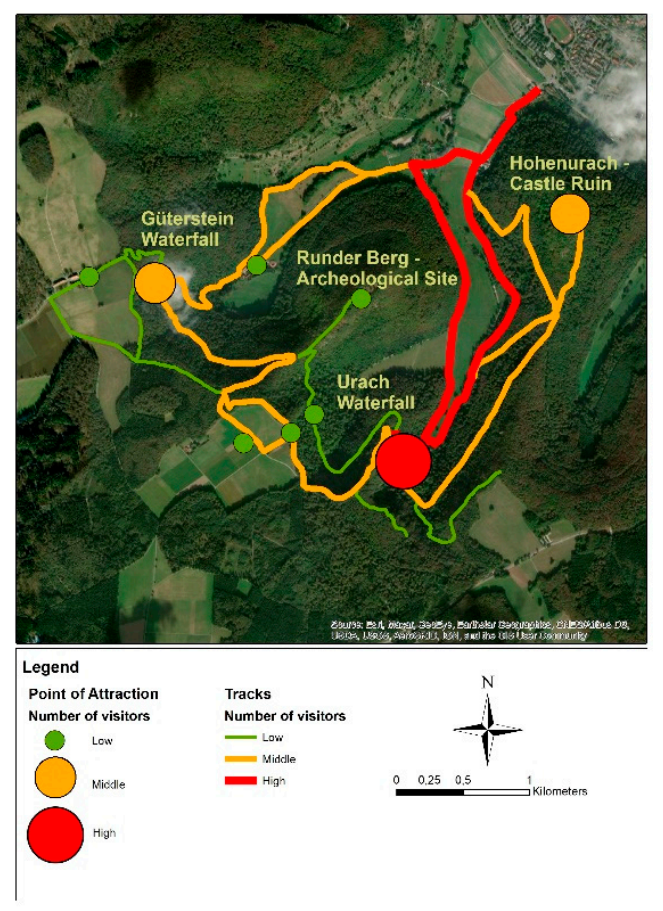

Figure 11. Number of visitors at Urach and Güterstein Waterfall UNESCO Global Geopark Swabian Alb, Germany (Author's design, based on Beuter 2010).

Despite their location within the UNESCO Global Geopark and their high tourist numbers, there are comparatively few valorization strategies. Information boards have been set up at the hikers' parking areas to provide some general information. The waterfalls are integrated into various hiking trails, including the Wasserfallsteig (waterfall path), which was declared the most beautiful hiking trail in Germany in 2016 [93].

A special mention should be made here of the interactive hiking tour 'Expedition Alb', which attempts to encourage visitors to read the landscape, i.e., to observe it closely and to gain an in-depth understanding of their observations. The accompanying brochure also introduces readers to geological and geomorphological features.

An adequate valorization strategy is urgently required, since there is a direct correlation between the endangerment of the geotopes and insufficient provision of information to visitors on how to protect them.

\section{Neidlingen Waterfall}

The Neidlingen Waterfall (Figure 1), which is significantly smaller than the waterfalls in the Urach district, formed completely naturally, in contrast to the two waterfalls cited above. Tufa was also never extracted [94]. Since the karst water level is highly dependent on precipitation, the springs feeding the Neidlingen waterfall can dry up after long periods of drought. The waterfall is then reduced to a dripping trickle. 
The Neidlingen waterfall is one of the Geopark's geopoints provided with an information board and integrated into a circular hiking trail. It attracts far fewer visitors than the two Urach waterfalls.

\subsubsection{Tufa Barrages}

These extensive calcareous tufa deposits, sometimes stretching to a length of several kilometers, formed in river valleys, such as the Erms, the Echaz, and the Wiesaz. They originated in the Holocene [47], predominantly in the warmer phases of the Atlantic (5000 to 3000 B.C.).

The thickness of these deposits is mostly between 5 and $8 \mathrm{~m}$ but can reach 14-15 $\mathrm{m}$ in places (Honau and Gönningen) and even up to a maximum of $30 \mathrm{~m}$ (Seeburg) [30]. The filling of entire valleys by these tufa deposits is explained by the fact that the river repeatedly obstructed its own course through these barrages and, therefore, deposited tufa within the whole valley [52]. Tufa barrages also boosted economic development in the foothills of the Alb. Their steep gradient, for example in the Erms Valley, facilitated generating electricity by means of hydropower [48]. This enabled the mechanization of the textile industry and thus the early industrialization.

On a smaller scale, tufa bars are still formed today at natural obstacles (such as tree trunks, stones, etc.) in flowing water. Sometimes, small water basins form upstream as, for example, in the Donn-Valley (see Figure 3).

\section{Seeburg Tufa Barrage}

In the Urach suburb of Seeburg, a $30 \mathrm{~m}$ thick tufa barrage formed over a period of approximately 10,000 years [30] (Figure 12). The tufa barrage dammed the local river Fischbach, creating a lake of up to $8 \mathrm{~m}$ depth and one kilometer in length, the so-called bottomless lake. In 1618, a $415 \mathrm{~m}$ long and $2.5 \mathrm{~m}$ high tunnel was driven through the tufa bar [95] in order to be able to periodically drain the lake for the benefit of the fishing industry. In 1821, the lake was completely drained to create space for settlement [42]. The heyday of tufa quarrying was in the second half of the 19th century, with around 60 stonecutters employed. In 1952, exploitation was stopped [30]. In 1996, the tunnel became a registered cultural monument [96]. Without knowing the historical background, the tufa barrage appears unspectacular. Every year in September on the 'Day of the open monument', a guided tour of the tunnel is organized. Apart from that there is no valorization. In contrast to the other tufa landforms, the massive tufa bar, visited only by a small number of people, is not at risk.

\section{Tufa Bars in the Upper Wiesaz Valley Near Gönningen}

In the upper course of the valley, the river Wiesaz has built up three mighty tufa terraces, including three small primary caves [42] (Figures 1 and 13). Between 1920 and 1975 , tufa was exploited on an industrial scale, by up to 80 workers, over an area of at least 16 ha [97]. Components for numerous buildings in the local and regional environment come from the Gönningen quarries, including probably the building stones of the castle portal at Tübingen (Figure 7).

In the 1930s, tufa blocks from Gönningen were used for the construction of the Olympic Stadium and the Reich Chancellery at Berlin [98], as well as for Munich Airport and the Volkswagen factory at Wolfsburg [55]. After the end of exploitation, some of the quarry pits filled with water, and they are now popular bathing lakes. The vast majority of today's visitors come for recreational purposes. Since 2003, they can take advantage of a tufa nature trail explaining special features of interest. 


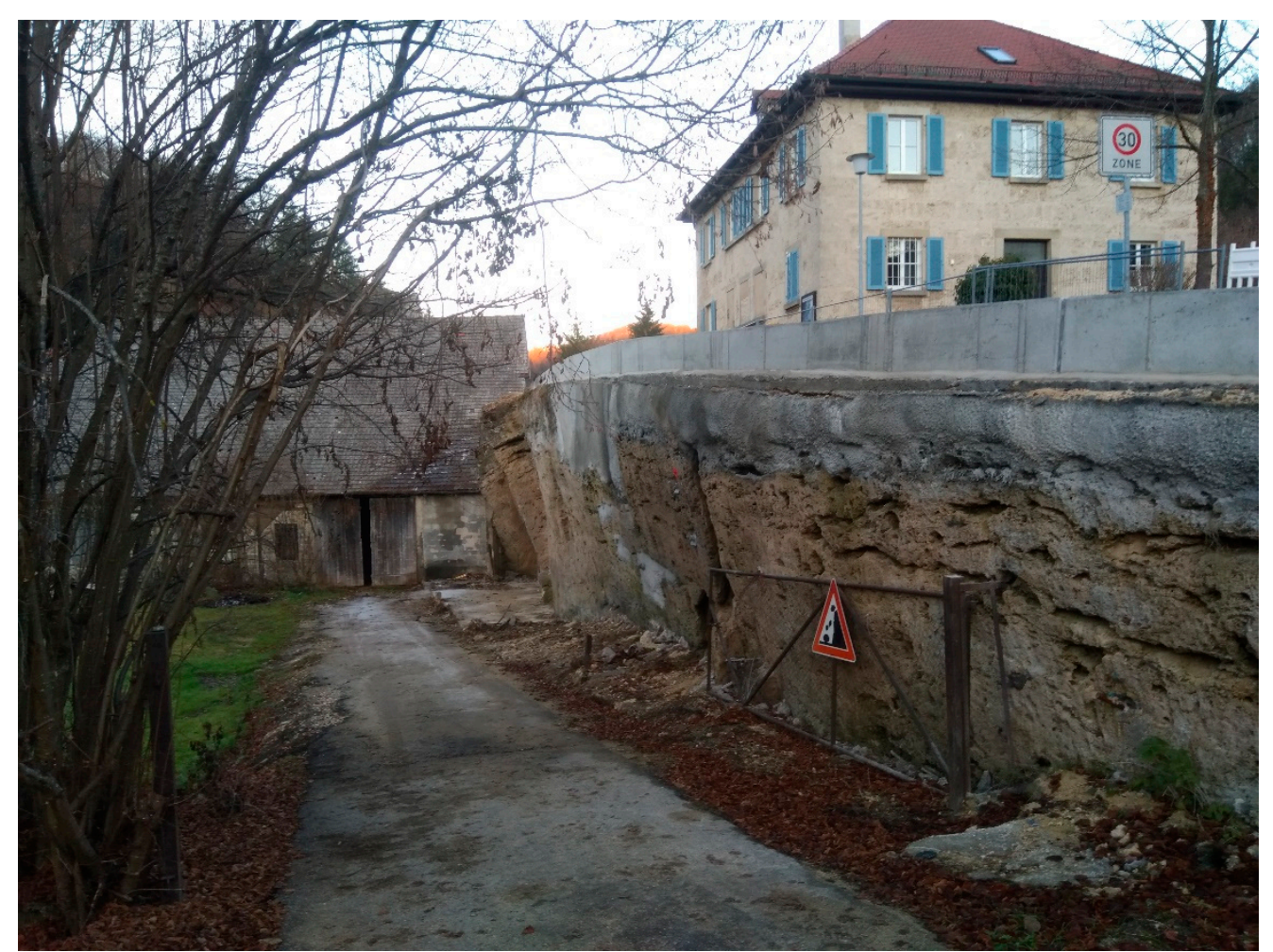

Figure 12. Tufa barrage in Seeburg (No. 4 in Figure 1) UNESCO Global Geopark Swabian Alb, Germany.

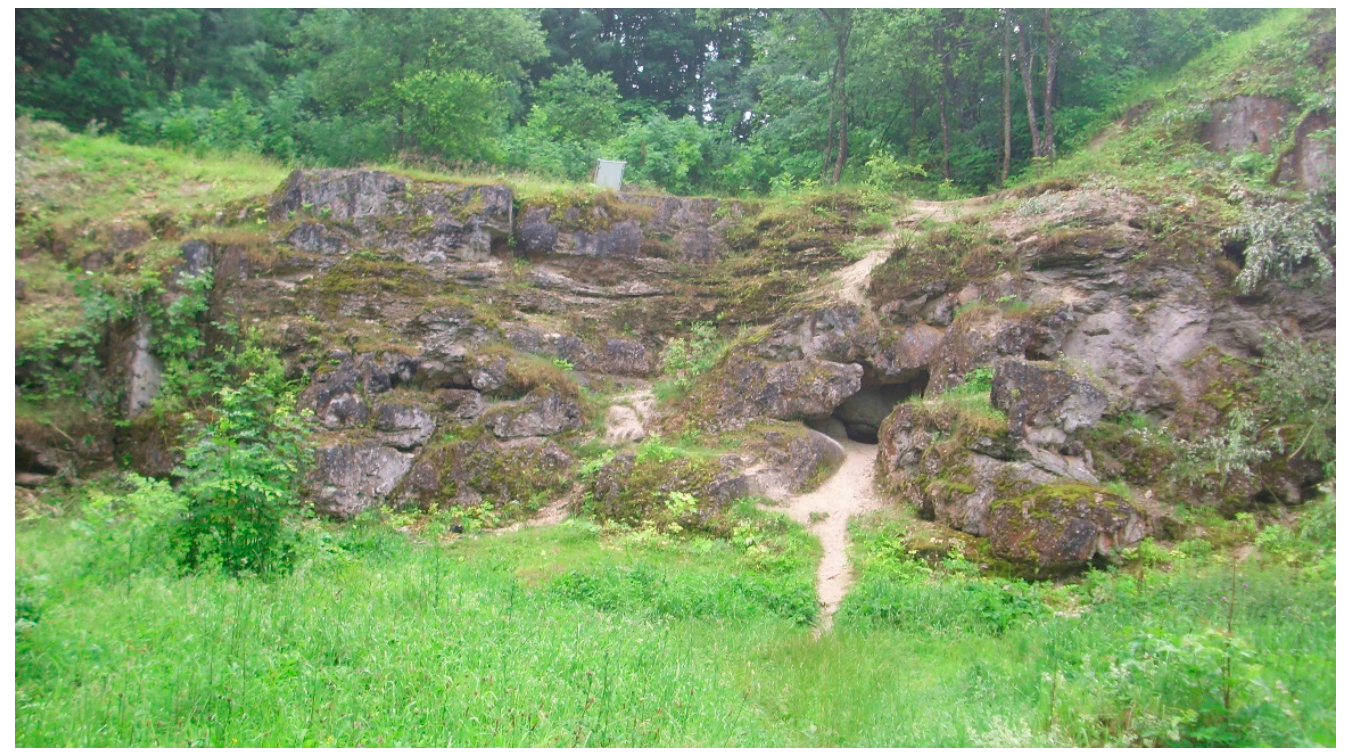

Figure 13. Tufa barrage and primary cave in Wiesaz-Valley (No. 5 in Figure 1) UNESCO Global Geopark Swabian Alb, Germany.

Water Basins in the Donn-Valley

In the Donn-Valley, numerous smaller tufa bars, with small water basins behind, have formed along a minor brook (see Figures 1 and 3). Various circular hiking trails are on offer to visitors of the Donn-Valley, but otherwise it is off the beaten track of geotourism.

Sinter Terraces at Gutenberg

Tufa bars rising to several meters height have formed in the river Lenninger Lauter. There are also numerous sinter terraces and basins on the valley slopes (Figures 1 and 5), 
which has inspired its description as a 'small piece of the Plitvice Lakes' or 'the Yellowstone National Park on the Swabian Alb'. The sinter terraces are promoted as one of the Geopark's geopoints.

\subsubsection{Primary Tufa Caves}

In the 1980s, [61] recorded a total of 33 tufa caves on the Swabian Alb. Only two of them are open to visitors. The other caves are either only accessible to speleologists or completely closed. Some of them have been converted into bunkers during wartime. Most of the tufa caves are short and narrow (Figure 13). Extensive quarrying has destroyed many tufa caves in the course of the last century.

\section{Olgahöhle (Cave Olga)}

The village of Honau is located on an 18 ha large and up to $30 \mathrm{~m}$ high tufa bar, which fills the entire width of the Echaz valley (Figure 1). In the past, tufa was mined here on a large scale. In 1874, the largest known tufa cave, its length as far as accessible exceeding $170 \mathrm{~m}$ and its height reaching three meters, was discovered. It was named in honor of Queen Olga [73]. Cave Olga is, however, in fact not a single cave, but consists of five largely independent caves, connected via artificial galleries to enhance its tourist appeal [61].

The Olga Cave is the oldest electrically illuminated show cave in Germany. Already in the 19th century, up to 10,000 visitors visited the cave per year. To introduce the necessary one-way-system an artificial exit was created [99]. Olga Cave contains a wide variety of tufa formations (Werner et al. 2013). Worth noting in particular is the pearl sinter, in German called "Blumenkohltuff" (cauliflower tufa), as it is reminiscent of oversized cauliflower heads (see Figure 14) [100].

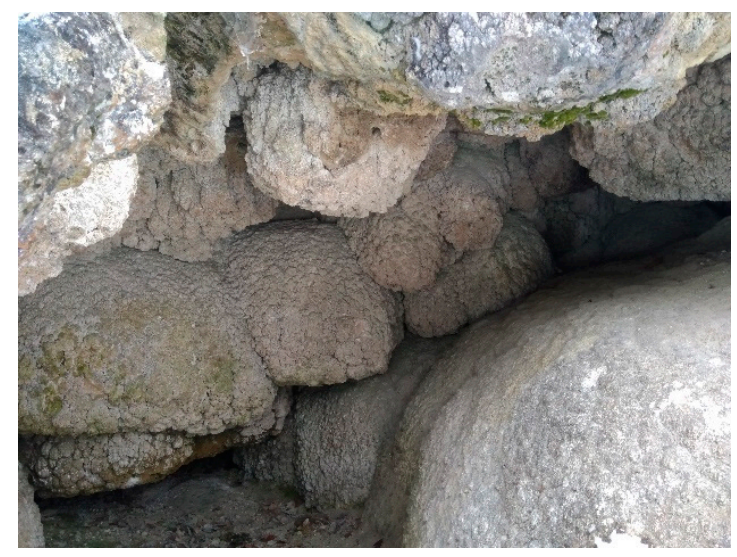

Figure 14. Cauliflower tufa in UNESCO Global Geopark Swabian Alb, Germany.

Due to the very restrictive opening hours (only one Sunday a month during the summer season) and access permitted only to participants of guided tours, the cave has suffered no serious harm.

\section{Tufa Cave at Zwiefaltendorf}

Zwiefaltendorf lies on a tufa bar, which the river Zwiefalter Ach deposited here in the boreal [42] (Figure 1). About six meters below the surface, a $27 \mathrm{~m}$ long, two to three meters wide and three to four meters high primary cave was discovered here in 1892, during the construction of a cellar under the brewery restaurant Rößle [95]. The cave has been accessible as a show cave since the last century. Due to initial illumination by magnesium torches and candles, the tufa formations are soot-blackened [42]. To visit the cave, one has to participate in a guided tour during the opening times of the restaurant above, and it is not of great tourist importance [61]. 


\subsection{Valorization of Calcareous Tufa within the UNESCO Global Geopark Swabian Alb}

Some well-known tufa geotopes on the Swabian Alb have been marketed as tourist destinations since the early phase of tourism in the 19th century, especially the Urach Waterfall famous all over the state of Baden-Württemberg. Many of the larger and more attractive tufa geotopes have also been popular excursion destinations in the region for many decades. Geotourism focuses on hiking trails, guided tours and information signs, as well as interactive self-guiding elements such as the so-called 'Expedition Swabian Alb' (see Section 4.1.1).

The Geopark's geotouristic map [101] and the book 'Erlebnis Geologie' (Adventure Geology) [100] list geotouristic destinations of particular interest. These include highlights, such as the tufa caves and the waterfalls at Urach, Güterstein, and Neidlingen. Map and book invite readers to discover the geological features. There is a concise description of each destination, but it lacks guidance on possible hazards and appropriate behavior. The criteria for selecting the chosen geotopes are not specified.

Ref. [102] developed for the first time a catalogue of criteria to determine the geotouristic potential and the possible valorization of the karst formations on the Swabian Alb. This was based on the criteria of accessibility, the safety of visitors, geotope protection, proximity to other geotopes and load-bearing capacity [102] (Figure 15). However, these criteria have so far only been systematically applied to sites within the municipality of Bad Urach.

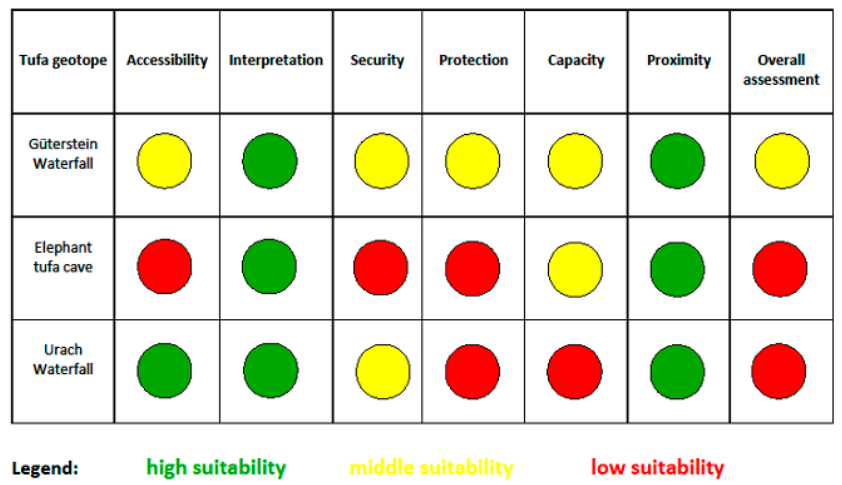

Figure 15. Assessment criteria (Author's design, based on [102]).

In the Geopark's geotope management plan [44], tufa landforms are not explicitly referred to, but subsumed under generic terms such as springs, rocks, waterfalls, etc. For all listed geotopes, the current use and condition (i.e., the degree of damage), accessibility, potential dangers, and the protection status are recorded. An overview map informs the general public. Outstanding geotopes are to be signposted and advertised as geopoints. Specific geotopes should also serve as educational sites for Geopark schools (i.e., schools closely cooperating with the Geopark and integrating geological topics into their curricula).

First and foremost, geotopes of a high geoscientific importance and with existing tourist infrastructure are to be developed for tourism. Geotopes designated as natural monuments or nature conservation areas should only be opened up for tourism, if there is no conflict of interest. Unfortunately, no systematic geotope evaluation was carried out and the concept was largely based on published data without verification on the ground or field survey. The evaluation of the current condition and the degree of deleterious developments are, therefore, in many cases incorrect. All the above-cited waterfalls and the sinter terraces at Lenningen-Gutenberg are considered to be in good conditions, which is unfortunately not the case.

The Geopark's homepage focuses on the most significant geotopes; this also includes all designated geopoints. Currently, however, there is no information on calcareous tufa landforms on this website, which is being revised. 
To date, there has been no comprehensive and systematic survey of all relevant geotopes within the Geopark, nor has their degree of endangerment or geotouristic potential been evaluated.

\subsection{Endangerment of Tufa Landforms within the UNESCO Global Geopark Swabian Alb}

Concerning the endangerment of the Geopark's tufa landforms, a distinction must be made between past developments, which have left their marks but no longer represent a problem today, and current threats. In the case of the latter, one has to distinguish between the repercussions of tourism and other threats. As to the former, the situation has worsened significantly in the year 2020, due to the Corona pandemic resulting in much-increased visits to local attractions.

\subsubsection{Historical Endangerments of Tufa Landforms}

As already pointed out in Section 2.2, tufa used to be very popular as a building stone. Historical quarrying, therefore, significantly altered many tufa landforms (with the exception of some tufa caves). The traces are often still clearly on view today (see Figure 10). In the Geopark, this mainly concerns the Urach and Güterstein waterfalls, as well as the tufa bars in the Wiesaz-Valley (Figure 13) and at Seeburg (Figure 12). Smaller tufa deposits, such as in the Donn-Valley (Figure 3) or at the Neidlingen waterfall, have been unaffected by quarrying.

Visitors do not seem to have posed a serious problem for the larger tufa landscape features in the past. No obvious alteration of the landscape is visible on a lithograph of the Urach waterfall from 1860. Even a century later, neither [52] nor [94] refer to any adverse impact of tourism at the waterfalls.

\subsubsection{Geoprotection as a Stepchild of Nature Protection}

To this day, there is much divergence between geotope and biotope conservation in Germany. Even the current version of the Federal Nature Conservation Act neither includes the term 'geotope' nor 'geotope protection'. While (cultural) landscape and soils are listed as worthy of protection for safeguarding the landscape's recreational value, as well as the ecosystem, important elements of our earth's history are not automatically protected by law [103].

Geotopes are, therefore, only protected if, due to their habitat function, they can be classified as biotopes worthy of protection according to $\S 30$ of federal law. This applies, for example, to rocky and steep coasts. Geotopes may be also protected, if they are designated as natural monuments due to 'their scarcity, special character, or outstanding beauty' (§ 23 federal law) or if geoparks are located within large-scale protected areas, which applies to 15 of the then 16 German geoparks [103]. There are no plans, however, to protect all geotopes. Only those geotopes 'distinguished by their special geological significance, rarity, intrinsic nature or beauty, and are of particular value for science, research, and teaching and for natural and cultural history' are meant to enjoy special protection [104].

Tufa forming springs are protected by federal and European (FFH) law, as they offer an unique habitat for plant species. [43], therefore, does not consider them to be under any acute threat. Unfortunately, this official protection status does not prevent these geotopes from being serious impaired.

\subsubsection{Current Threats to the Tufa Landforms in the UNESCO Global Geopark Swabian Alb}

Tufa springs and waterfalls, which depend on a regular supply of uncontaminated water, react very sensitively to changes in the water supply due to climate change. During the summer months there are always times, when the Neidlingen waterfall shrinks to a meagre trickle because the Lindach Springs almost run dry. Eutrophication or contamination of the water can also seriously affect tufa forming springs.

Since the Swabian Alb is the largest karst area in Germany, contaminants, e.g., from animal husbandry or the application of fertilizers, enter the water supply of the tufa 
springs unfiltered. Eutrophication has negative effects especially on highly specialized plant communities and thus also on the formation rate of tufa. Caves and tufa bars, most of which have formed in earlier geological epochs, are less affected.

The most serious dangers to tufa geotopes result from excessive numbers of visitors and improper behavior. Even before the Corona pandemic, some places experienced an extensive negative impact of overtourism, defined as 'the impact of tourism on a destination, or parts thereof, that excessively and adversely influences the perceived quality of life of locals and/or the quality of visitors' experiences' [54].

This problem has worsened dramatically during the Corona pandemic. Severe restrictions on travel abroad, as well as on numerous other leisure activities, have led to a rediscovery of the surrounding homeland ('Heimat'). The number of visitors to local natural areas, for recreation, walking, cycling, hiking, etc., not only increased significantly, but also meant that parts of the population that had not previously frequented local attractions in the countryside, including increasingly those with a migration background, have discovered natural sites at their doorsteps [105]. This not only increased the absolute number of visitors, but also the number of people who are either unaware of, or even indifferent to, appropriate behavior in nature. Due to the much-increased pressure, some sensitive natural areas have suffered considerably. Severe measures, such as barring all visitor access (Figure 16), had to be implemented at some sites. Vulnerable tufa landforms have been particularly affected. Not only the Geopark, but also other protected areas faced challenges [40], some of them seeing a two-fold increase in visitor numbers. We assume that other hotspots in the Geopark experienced a similar surge in visits, but this has, unfortunately, not been monitored and no statistical data are available. In all protected areas, overcrowding (mainly caused by domestic visitors) and problems related to motorized traffic (e.g., an increase in volume and parking in non-designated areas), problematic behavior (e.g., littering, pollution through dog or human waste, noise nuisance, and illegal or unauthorized activities) and conflicts between visitors and local residents, mostly as a result of overcrowding and trespass into private property, were reported.

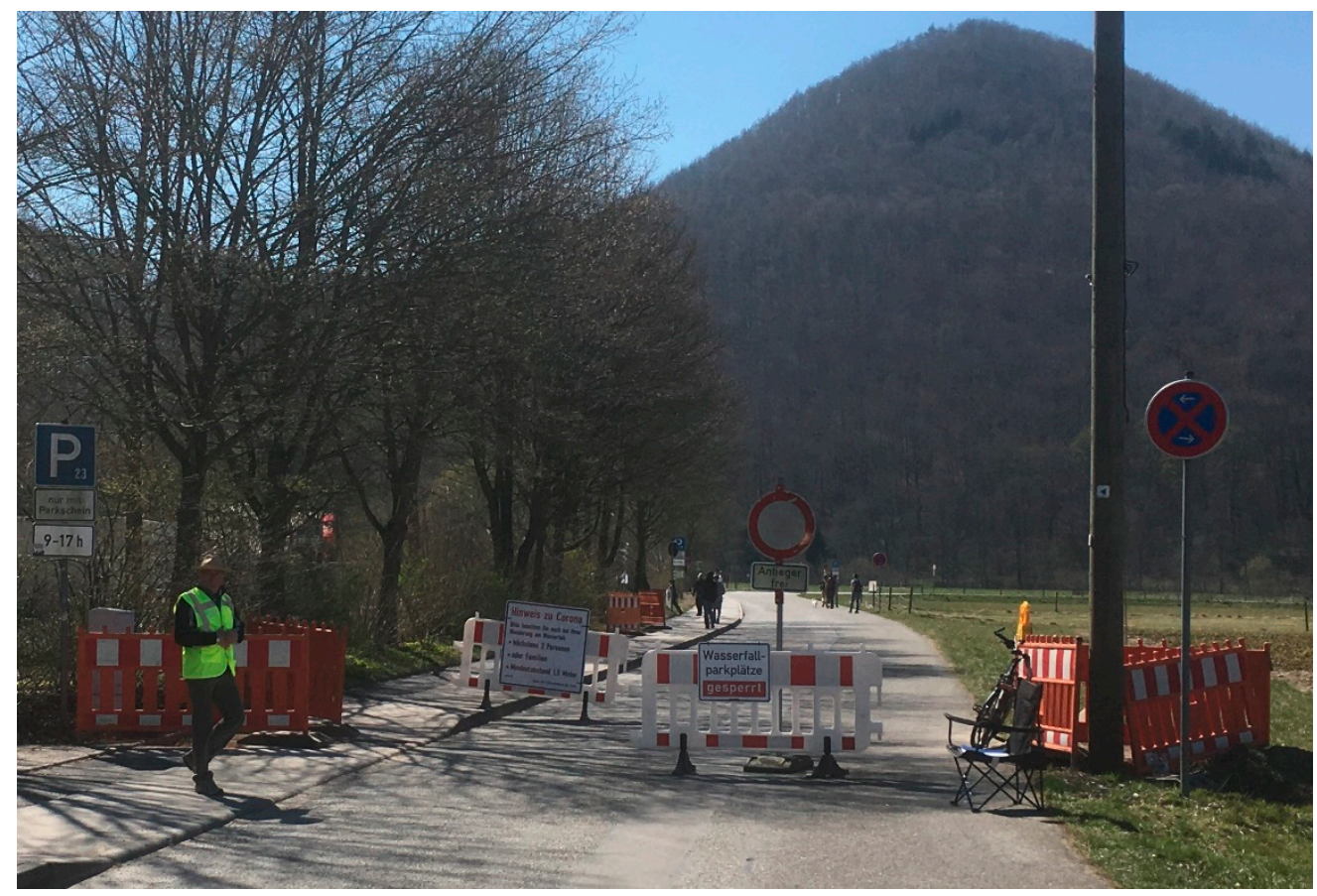

Figure 16. Entrance barrier at Urach Waterfall (No. 1 in Figure 1) UNESCO Global Geopark Swabian Alb, Germany. (Mall 2020).

An increase in the number of visitors can generate a feeling of crowding and discomfort among some visitors, notably if expecting to find peace and quiet in nature [106]. On 
the other hand, for the current generation of tourists visiting an overcrowded natural area may not be as problematic as it would have been a few decades ago [107], especially for city-dwellers who hardly ever ventured into natural areas prior to the pandemic.

Endangerment of the Urach and Güterstein Waterfalls

The frequently high number of visitors at both waterfalls (Figures 11 and 17), exacerbated by insufficient visitor guidance and information on how to protect nature, has had a serious adverse effect on both waterfalls, mainly due to trampling damage and nutrient inputs (see Figure 4 and $[63,65]$ ).

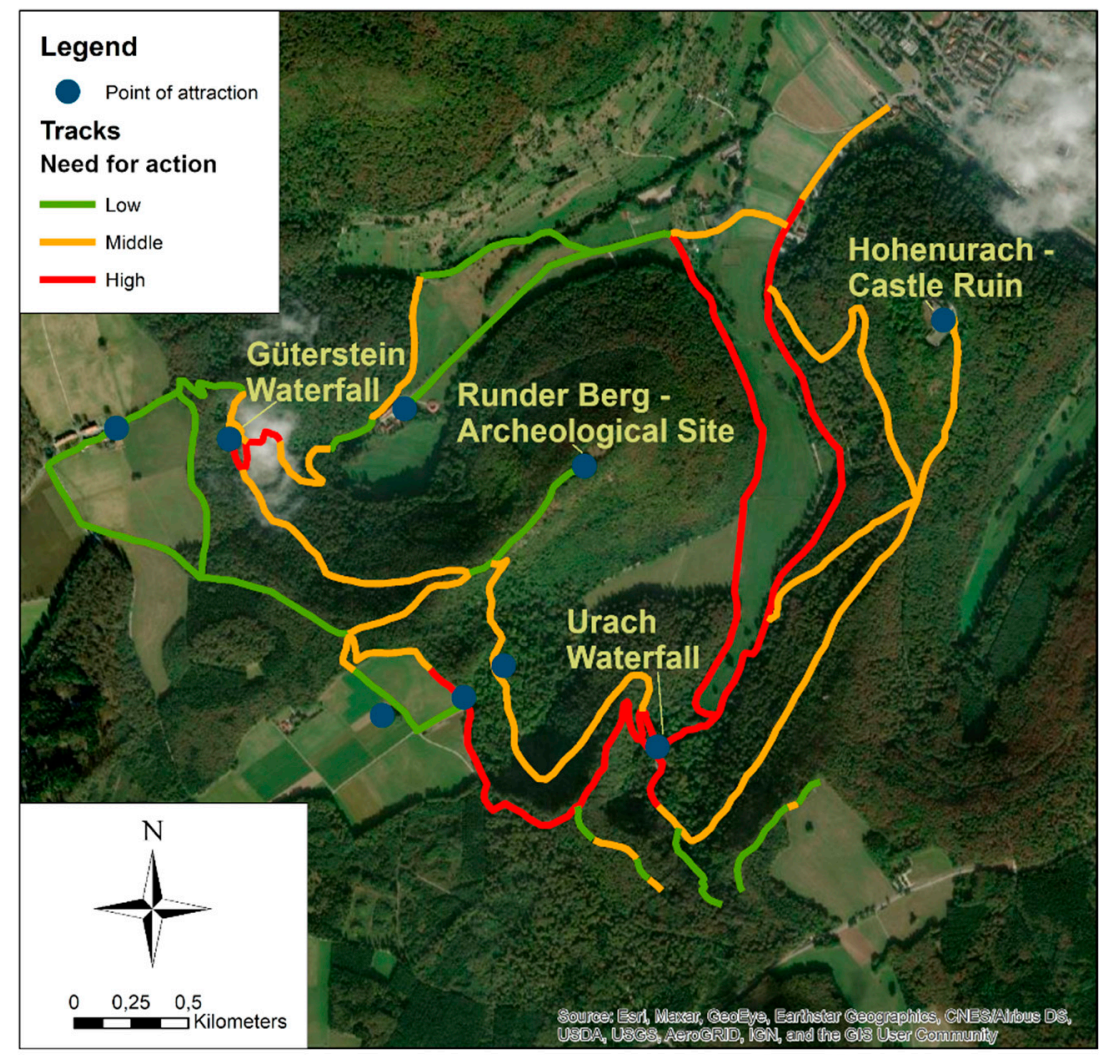

Figure 17. Need for action on access paths to the Urach and Güterstein Waterfall (No. 1 and 2 in Figure 1) and main attraction points nearby, UNESCO Global Geopark Swabian Alb, Germany (Author's design, based on Beuter 2010).

This is mostly due to visitors' lack of knowledge. Although significantly more information on nature preservation has been available to the general public over the past decade than had been the case before, Beuter's surveys still show considerable information deficits among visitors. Over half of the people visiting the Swabian Alb saw no need to obtain new information [92]. Currently, there is no guidance easily accessible to visitors in the immediate vicinity of the waterfalls, except for a sign discouraging people from leaving the path. Numerous trampling paths, however, make it difficult even to recognize the official route. This leads to further damage. Furthermore, a survey has shown that almost $80 \%$ of the visitors were aware of the serious harmful effects wandering off the official route could have on mammals and plants, but only just over $60 \%$ were conscious of the impact on the very vulnerable tufa. In the case of calcareous tufa, some did not suspect any impact at all or preferred not to make any statements due to their lack of knowledge (Figure 18). 


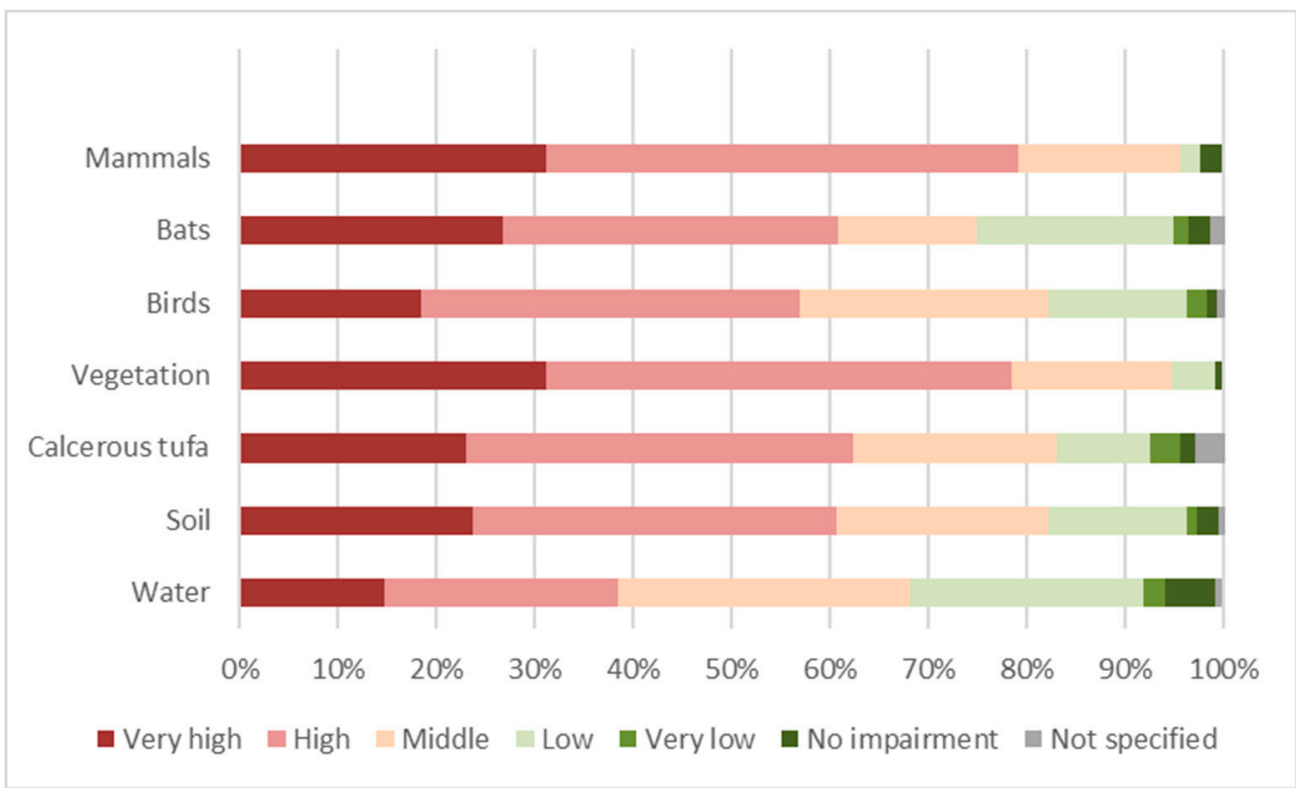

Figure 18. Results of a survey among visitors to the UNESCO Global Geopark Swabian Alb about potential harmful effects by wandering of the official routes at Urach Waterfall (Author's design, based on Beuter 2010).

Damage is also caused by the rapidly increasing phenomenon of taking selfies. In order to take a perfect selfie with the waterfall in the background, visitors have to leave the path and venture onto the tufa terraces (Figure 19). As a result, the tufa was in parts completely destroyed by trampling damage. Such selfies also feature prominently on travel blogs and other internet sites, and thus encourage people to follow the example.

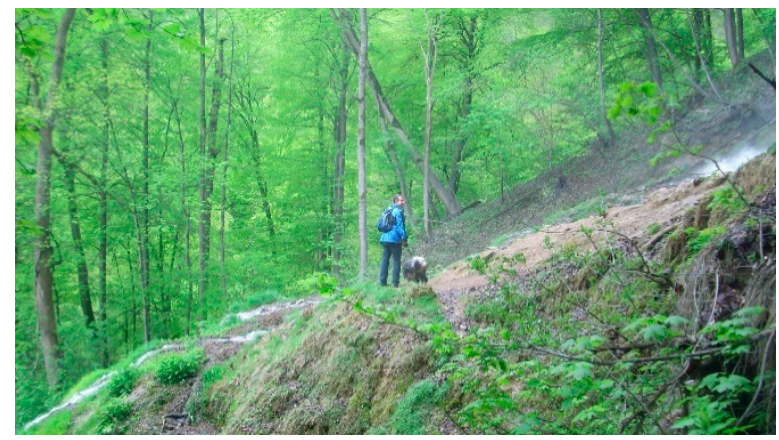

Figure 19. Tourist with dog standing on tufa terrace below Urach Waterfall, UNESCO Global Geopark Swabian Alb, Germany.

A recent survey at the Urach Waterfall has shown that many visitors have not even noticed the damage. Overall, $40 \%$ rated nature and the 'naturalness' as very positive [108]. This means that visitors lack the knowledge to recognize the eutrophication of the vegetation and the destruction of the tufa terraces. Shockingly, this was even the case for employees of nature conservation agencies.

During the first lockdown during the Corona pandemic in March 2020, there were 'mass migrations' on the access roads to, and in the immediate vicinity of, the Urach waterfall, especially on weekends with good weather. Parking spaces soon ran out of capacity and hundreds of cars were parked along the farm tracks and in nearby meadows. At the peak phase more than 2000 cars were counted at the parking spaces near the waterfalls (Figure 20). 


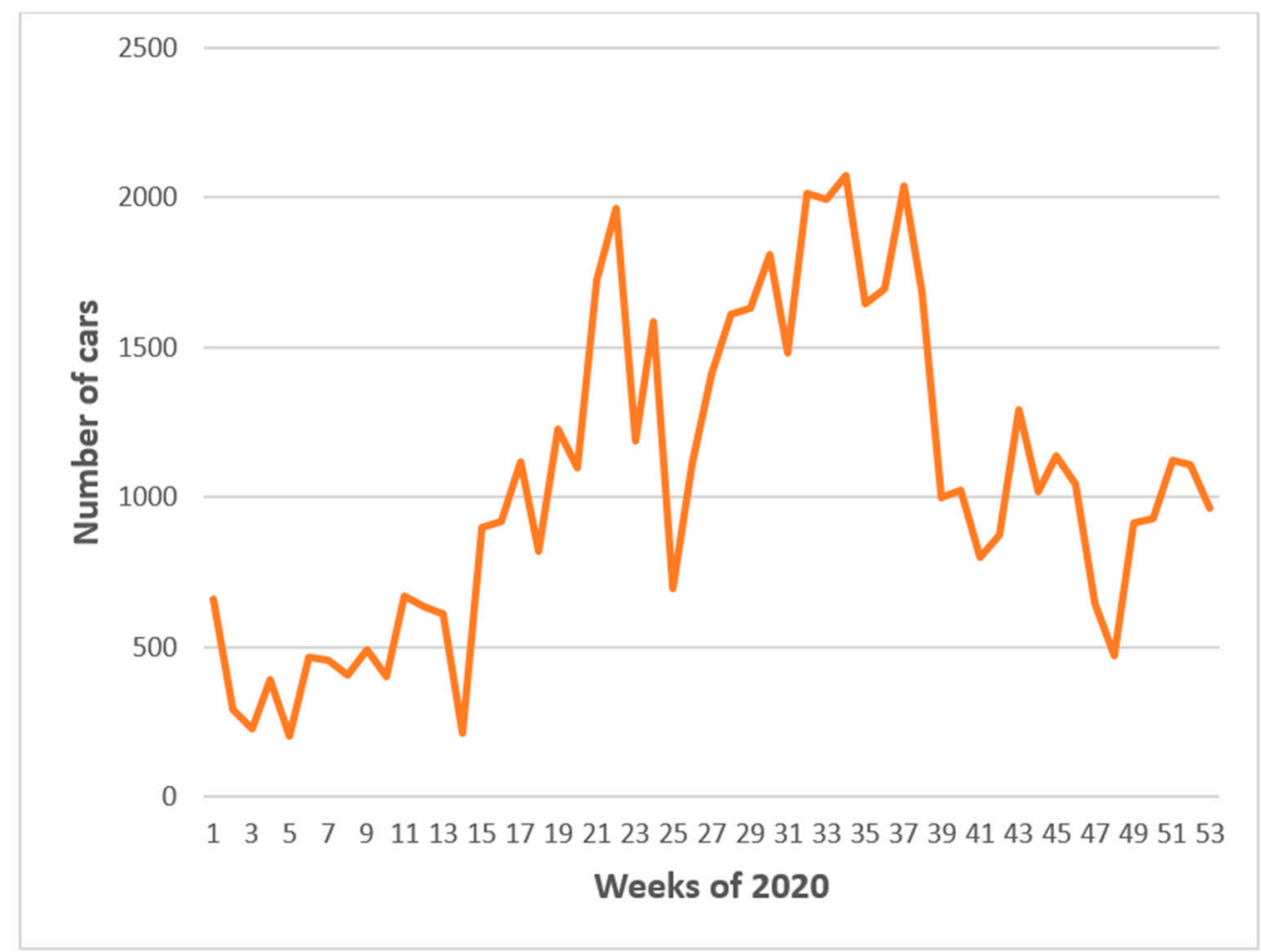

Figure 20. Visitor numbers at Urach waterfall (UNESCO Global Geopark Swabian Alb, Germany) based on the number of parked vehicles in the course of 2020 (105].

Trampling damage increased considerably as a result of the explosion in visitor numbers. The authorities at Bad Urach were forced to close both the award-winning hiking trail and the majority of car parks. The police were on duty on horseback around the waterfall. After the situation had temporarily calmed down over the summer, visitor numbers surged again in the course of the second lockdown in November 2020. Yet, on this occasion, neither barriers were installed nor did the police take action. The city merely appealed to the common sense of visitors.

\section{Neidlingen Waterfall}

Fewer people visit the lesser-known Neidlingen Waterfall, even during the current Corona pandemic. Even here, however, people approach the waterfall via numerous unofficial paths, to get closer to the natural spectacle for a good photo. Children often try to reach the tufa nose from above. An unfortunately phrased information board for the Geopoint ('Directly along the path you can find encrusted twigs and leaves that clearly crackle when crushed in the hand') inadvertently encourages people to look for such tufa formations and to crush and destroy them.

Tufa Bars and Water Basins in the Donn-Valley

As shown on Figure 3, tufa bars with small water basins formed in the Donn-Valley. These are easily accessible via the adjacent meadows and, due to the low water level, are a wonderful water playground, especially for smaller children. The Donn-Valley is, however, a nature reserve and within the core zone of the biosphere reserve Swabian Alb. Visitors have to respect the restricted walkways and a ban on pedestrian access to the meadows and the creek.

The tufa bars and water basins in the Donn-Valley were in a largely pristine condition prior to the Corona crisis. Since visitor numbers were within tolerable limits before, there was no particular need for action. During the Corona pandemic, public outdoor and indoor swimming pools and bathing lakes were initially closed in Germany, and later only accessible with extensive restrictions and a limit on visitor numbers. Bathers had 
to make reservations in advance and keep at a distance of $1.5 \mathrm{~m}$ to other visitors. With such restrictions in place and the summer in 2020 being exceptionally warm and dry, the pressure on natural water pools, that were not subject to these restrictions, increased greatly.

During the pandemic, internet platforms, such as 'Outdoor active', etc., increasingly disseminated information about accessible waters. Such posts touted the Donn-Valley as an ideal bathing destination for families. Even people who had never heard about the small valley before, and some from afar, were now encouraged to visit. Hardly known outside the region before, the Donn-Valley attracted 3000 visitors on Google maps in May and 4000 in July. Mirroring developments at waterfalls, numerous people came to the Donn-Valley who were not familiar with adequate behavior in natural landscapes. Nature reserve signs were ignored. Additional boards, explaining the reason for protecting the area (see Figure 21), also had only a minor effect. The delicate tufa deposits suffered greatly from the much-increased footfall, the surrounding area was littered with rubbish, meadows and residential areas were full of cars. The small and normally quiet valley was overrun by such crowds, that the municipality eventually had to close off the area.

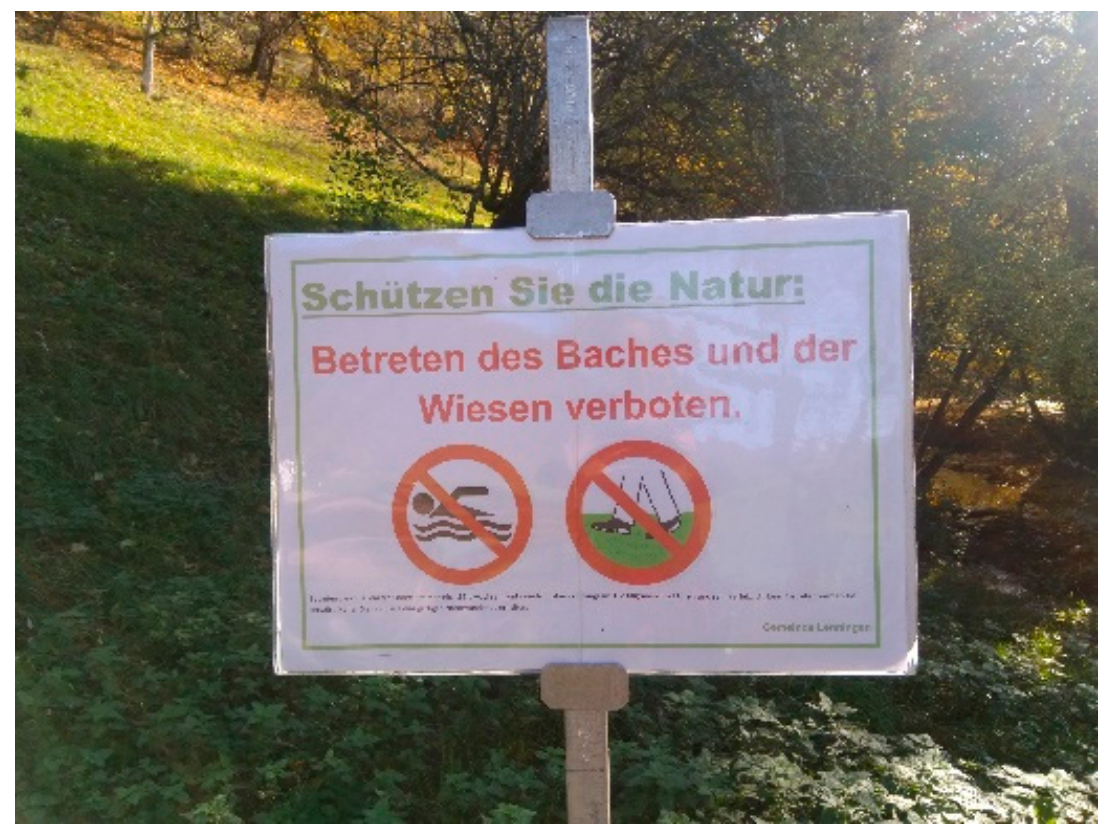

Figure 21. Prohibition sign in Donn-Valley (No. 6 in Figure 1) in UNESCO Global Geopark Swabian Alb, Germany.

\section{Discussion}

Our results clearly show, that the UNESCO Global Geopark Swabian Alb includes high valuable tufa geotopes, but being partly damaged and endangered by visitor numbers and behavior. These impairments worsened significantly during the Corona pandemic.

Our surveys are consistent with observations from other national and international geoparks. Here, too, high-quality tufa landforms are attraction factors for high visitor numbers [26-28] but are also subject to increasing degradation and endangerment as a result [15-17,54,62-68]. This is due to the high vulnerability of the Tufa landforms, particularly cascades and sinter basins [62,63].

Significantly increased number of visitors to recreational and protected areas accessible for a day trip have been observed in many parts of the Geopark Swabian Alb, as well as in other national and international nature reserves [40].

Since geotourism makes an increasingly important contribution to regional added value, especially in rural-peripheral areas $[65,109]$, and since geotope protection is an essential task of geoparks [76], protection measures are urgently needed [31-36].

If an increase in visitors might be detrimental to conservation goals, several measures can be taken. First, the access to vulnerable sites has to be restricted. Such restrictions 
have been applied not only in the UNESCO Global Geopark Swabian Alb, but also at Plitvice (Croatia) or Pamukkale (Turkey) to cite just two examples, in order to reduce the impact [107]. Second, infrastructure should be adapted to accommodate a growing number of tourists. The later measure, however, is not a viable option for the UNESCO Global Geopark's tufa formations, as for most of them the number of visitors is already beyond carrying capacity. Additionally, environmentally conscious tourists might be dissatisfied with built-up natural areas, which fail to conform to their 'ideals of nature' [110].

The clear deficits in geotope protection are partly due to a lack of understanding of the need for protection of 'inanimate' rocks and landscape forms, whereas the need for protection of plants and animals is much easier to convey (see Figure 18). Geotopes that have no or no sufficient legal protection can, therefore, only be safeguarded and maintained in a good condition if the public appreciates their importance and their vulnerability. Thus, geo-education is of particular importance in promoting an understanding of the need for protection [111], not only among the wider public [62], but even among specialists in cognate disciplines, such as biology [112].

Some groups of visitors, however, who during the Corona pandemic were increasingly on the move within natural areas, are indifferent to any damage to geotopes. This explains parking on meadows and littering. Raising awareness is only of limited help here. Gentle measures can reduce the number of parking spaces and delete internet entries that encourage irresponsible behavior. The municipality of Lenningen was able to reduce the damage to the sinter terraces and in the Donn-Valley significantly through extensive parking bans. The registration as owner of the geotopes enabled the municipality also to have problematic Internet entries deleted.

Visitor guidance can help sensitive areas. Suitable measures to reduce the impact include blocking unofficial paths, e.g., via barriers at entrance points. At the Dissen sinter terraces in the Geopark Teutoburg Forest, there is a boardwalk for visitors, with signs informing them of the problems caused by leaving the path. The deployment of rangers has also proven to be effective. They are on duty on hot spots in Geopark Swabian Alb at weekends and intervene in cases of misconduct.

At the pandemic peak of the visitor rush, however, only drastic measures proved effective (see above). These are comparable to measures taken by other heavily affected protected areas to tackle such challenges. They include information campaigns, traffic management, and establishing a system of one-way trails. Measures to safeguard public health are, however, often in conflict with protected areas management measures aiming to minimize disturbance of wildlife and ecosystems [40]. Furthermore, local communities face a dilemma between promoting tourism and a positive image of the region and the necessity to implement unpopular measures to protect nature. The municipality of Bad Urach has now commissioned a visitor guidance concept to be developed.

\section{Conclusions}

Geotourism has become an increasingly popular form of theme tourism [2-8] and over the last decade one of the fastest growing branches of tourism [9]. Karst landscapes are especially popular, with caves being the most visited geotouristic features across the globe [11-14]. Calcerous tufa and sinter are among the most impressive natural spectacles in karst landscapes, whose scientific and aesthetic values are universally recognized [15-25]. They, therefore, attract a growing number of visitors [26-28] but are unfortunately extremely vulnerable and can be seriously damaged even by minor inference. The rediscovery of the "Heimat" (homeland), associated with a significant increase in visitors to natural areas led to negative repercussions for the environment [40]. Numerous authors already addressed the problem of increasing endangerment of the geoheritage [2-8,10,30-38].

Not only our results show that extensive geotope protection combined with specific geo-education for a lay audience and an adequate visitor guidance system are urgently needed. 
Research perspectives for further investigations therefore lie mainly in the following four topics:

$>$ Methods of geoconservation, especially for highly vulnerable geotopes like tufa cascades; $>$ Scientific evaluation and further development of geo-education for a recreational audience so that awareness of geotope conservation can be successfully created;

$>$ Scientific evaluation and further development of visitor guidance not only at specific sites, but also in the whole area;

$>$ Effects of overtourism in sensitive areas and action strategies adapted to them.

In our case study, the UNESCO Global Geopark Swabian Alb is currently developing a new master plan that will address the problem areas mentioned above.

Funding: This research received no external funding.

Institutional Review Board Statement: Not applicable.

Informed Consent Statement: Not applicable.

Data Availability Statement: Not applicable.

Acknowledgments: The author is very grateful to Maik Kessler for his valuable support for the maps included in this article, to Eberhard Sauer for reviewing the English text, to Hans-Martin Luz for his support during the site inspections, as well as his valuable suggestions as an experienced area expert, to Torsten Clement for extensive data on the pandemic situation at Bad Urach and to Bernd Mall and Till Langrehr for the print approval of their photos. The author is also grateful to the two anonymous reviewers for their helpful suggestions.

Conflicts of Interest: The author declares no conflict of interest.

\section{References}

1. Hose, T. Geotourism-Appreciating the deep time of landscapes. In Niche Tourism, Contemporary Issues, Trends and Cases; Novelli, M., Ed.; Routledge: London, UK, 2004; pp. 27-37.

2. Dowling, R.; Newsome, D. Handbook of Geotourism; Edward Elgar Publishing: Cheltenham, UK, 2018 ; ISBN 1785368850.

3. Dowling, R.; Newsome, D. Geotourism; Routledge: Amsterdam, The Netherlands, 2010; ISBN 978-1906884093.

4. Newsome, D.; Dowling, R. Geoheritage and Geotourism. In Geoheritage: Assessment, Protection, and Management; Reynard, E., Brilha, J., Eds.; Elsevier: Amsterdam, The Netherlands, 2018; pp. 305-321, ISBN 9780128095317.

5. Reynard, E.; Brilha, J. Geoheritage: Assessment, Protection, and Management; Elsevier: Amsterdam, The Netherlands, 2018; ISBN 9780128095317.

6. Chen, A.; Lu, Y.; Ng, Y.C.Y. The Principles of Geotourism; Springer: Berlin/Heidelberg, Germany, 2015; ISBN 978-3-662-46696-4.

7. Reynard, E.; Coratza, P. Geomorphosites; Friedrich-Pfeil-Verlag: Munich, Germany, 2009; ISBN 978-3899370942.

8. Megerle, H. Geotourismus. Innovative Ansätze zur Touristischen Inwertsetzung und Nachhaltigen Regionalentwicklung; Kersting-Verlag: Rottenburg am Neckar, Germany, 2008; ISBN 3-937559-09-4.

9. Olafsdottir, R. Geotourism. Geosciences 2019, 9, 48. [CrossRef]

10. Singh, R.B.; Wei, D.; Anash, S. Global Geographic Heritage, Geoparks and Geotourism. Geoconservation and Development. In Advances in Geographical and Environmental Sciences; Springer: Singapore, 2020; ISBN 978-981-15-4955-7.

11. Cigna, A.; Forti, P. Caves: The most important geotouristic feature in the world. Tour. Karst Areas 2013, 6, 9-26.

12. Vorlaufer, K. Karst und Tourismus. Geogr. Rundschau 2005, 57, 34-43.

13. Migon, P. Development of karst phenomena for geotourism in the Moravian Karst (Czech Republic). Geotourism 2011, 3-4, 26-27.

14. Antić, A.; Tomić, N.; Marković, S. Karst Geoheritage and Geotourism Potential in the Pek River Lower Basin (Eastern Serbia). Geogr. Pannonica 2019, 23, 32-46. [CrossRef]

15. Šiljeg, A.; Marić, I.; Cukrov, N.; Domazetović, F.; Roland, V. Multiscale Framework for Sustainable Management of Tufa-Forming Watercourses: A Case Study of National Park "Krka", Croatia. Water 2020, 12, 3096. [CrossRef]

16. Qiao, X.; Du, J.; Lugli, S.; Ren, J.; Xiao, W.; Chen, P.; Tang, Y. Are climate warming and enhanced atmospheric deposition of sulfur and nitrogen threatening tufa landscapes in Jiuzhaigou National Nature Reserve, Sichuan, China? Sci. Total Environ. 2016, 562, 724-731. [CrossRef]

17. Gu, Y.; Du, J.; Tang, Y.; Qiao, X.; Bossard, C.; Deng, G. Challenges for sustainable tourism at the Jiuzhaigou World Natural Heritage site in western China. Natur. Resour. Forum 2013, 37, 103-112. [CrossRef]

18. Capezzuoli, E.; Gandin, A.; Pedly, M. Decoding tufa and travertine (fresh water carbonates) in the sedimentary record: The state of the art. Sedimentology 2014, 61, 1-21. [CrossRef]

19. Nicoll, K.; Sallam, E. Paleospring tufa deposition in the Kurkur Oasis region and implications for tributary integration with the River Nile in southern Egypt. J. Afr. Earth Sci. 2017, 136, 239-251. [CrossRef] 
20. Chen, J.; Zhang, D.D.; Wang, S.; Xiao, T.; Huang, R. Factors controlling tufa deposition in natural waters at waterfall sites. Sediment. Geol. 2004, 166, 353-366. [CrossRef]

21. Pedley, M. Tufas and travertines of the Mediterranean region: A testing ground for freshwater carbonate concepts and developments. Sedimentology 2008. [CrossRef]

22. Sallam, E. Ancient tufa and semi-detached megaclasts from Egypt: Evidence for sedimentary rock classification development. Int J. Earth Sci. 2019, 108, 1615-1616. [CrossRef]

23. Viles, H.; Goudie, A. Tufas, travertines and allied carbonate deposits. Prog. Phys. Geogr. Earth Environ. 1990. [CrossRef]

24. Viles, H.; Pentecost, A. Tufa and Travertine. In Geochemical Sediments and Landscapes; Nash, D., McLaren, S., Eds.; Blackwell Publishing Ltd.: Hoboken, NJ, USA, 2007; pp. 173-199, ISBN 978-1405182454.

25. Sallam, E.S.; Abou-Elmagd, K. Paleospring freshwater tufa carbonates of the Kurkur Oasis Geosite (southern Egypt): Archives for paleoenvironment and paleoclimate. Int. J. Earth Sci. 2021. [CrossRef]

26. Gračan, D.; Zadel, Z.; Rudančić, A. Management of sustainable tourism development: Case Study Plitvice Lakes National Park International. J. Manag. Cases 2011, 13. [CrossRef]

27. Mari, L.; Telbisz, T. European National Parks with karst landscapes. In Modern Approaches and Applications towards the 2030 Agenda, Proceedings of the IX Symposium ProGeo.; Głowniak, E., Wasiłowska, A., Leonowicz, P., Eds.; Faculty of Geology, University of Warsaw: Warsaw, Poland, 2017; pp. 94-95, ISBN 978-83-945216-5-3.

28. Liu, L. Factors Affecting Tufa Degradation in Jiuzhaigou National Nature Reserve, Sichuan, China. Water 2017, 9, 702. [CrossRef]

29. World Tourism Organization (UNWTO). "Overtourism"-Understanding and Managing Urban Tourism Growth beyond Perceptions; Executive Summary: Madrid, Spain, 2018.

30. AbdelMaksoud, K.; Al-Metwaly, W.; Ruban, D.; Yashalova, N. Sand dune migration as a factor of geoheritage loss: Evidence from the Siwa Oasis (Egypt) and implications for geoheritage management. Proc. Geol. Assoc. 2019, 130, 599-608. [CrossRef]

31. Crofts, R.; Tormey, D.; Gordon, J. Introducing New Guidelines on Geoheritage Conservation in Protected and Conserved Areas. Geoheritage 2021. [CrossRef]

32. Crofts, R. Putting Geoheritage Conservation on All Agendas. Geoheritage 2018, 10, 231-238. [CrossRef]

33. Gordon, J.; Crofts, R.; Díaz-Martínez, E.; Woo, K. Enhancing the Role of Geoconservation in Protected Area Management and Nature Conservation. Geoheritage 2017. [CrossRef]

34. Crofts, R.; Gordon, J.E.; Brilha, J.; Gray, M.; Gunn, J.; Larwood, J.; Santucci, V.L.; Tormey, D.; Worboys, G.L.; Groves, C. Guidelines for Geoconservation in Protected and Conserved Areas; IUCN: Gland, Switzerland, 2020. [CrossRef]

35. Gregorič, A.C. Typical Doline and Surface Landforms of Kras (Slovenia): Karst Landscape Features and Possibilities for Their Conservation. Geoheritage 2021, 13, 26-100. [CrossRef]

36. Wimbledon, W.; Smith-Meyer, S. Geoheritage in Europe and Its Conservation; ProGEO: Oslo, Norway, 2012; ISBN 978-82-426-2476-5.

37. Gordon, J. Geoheritage, Geotourism and the Cultural Landscape: Enhancing the Visitor Experience and Promoting Geoconservation. Geosciences 2018, 8, 136. [CrossRef]

38. Coratza, P.; Panizza, M. Geomorphology and cultural heritage. Mem. Descr. Della Carta Geol. Italia 2009, 87, 1-189.

39. Skare, M.; Riberio Soriano, D.; Porada-Rochoń, M. Impact of COVID-19 on the travel and tourism industry. Technol. Forecast. Soc. Chang. 2020. [CrossRef]

40. McGinlay, J.; Gkoumas, V.; Holtvoeth, J.; Armas Fuerts, R.F.; Bazhenova, E.; Benzoni, A.; Botsch, K.; Cabrera Martel, C.; Carrillo Sanchez, C.; Cervera, I. The Impact of COVID-19 on the Management of European Protected Areas and Policy Implications. Forests 2020, 11, 1214. [CrossRef]

41. Burgmeister, G.; Schöttle, M. Geotope im Regierungsbezirk Stuttgart; Kraft-Druck: Ettlingen, Germany, 2002; ISBN 3-88251-283-0.

42. Schöttle, M. Geotope im Regierungsbezirk Tübingen. Available online: https://pudi.lubw.de/detailseite/-/publication/45542 (accessed on 2 October 2020).

43. Landesanstalt für Umwelt Baden-Württemberg. FFH-Lebensraumtyp 7720 Kalktuffquellen. Available online: https:/ /www.lubw. baden-wuerttemberg.de/natur-und-landschaft/7220-kalktuffquellen (accessed on 17 November 2020).

44. Pietsch, D.; Huth, T. Geotopmanagementkonzept; Geotopdokumentation 2017; UNESCO Global Geopark Schwäbische Alb: Schelklingen, Germany, 2017; unpublished report.

45. Heizmann, E.; Speidel, W. GeoPark Schwäbische Alb—Neue Chancen und Perspektiven für eine Region? In Geotourismus, Innovative Ansätze zur Touristischen Inwertsetzung und Nachhaltigen Regionalentwicklung; Megerle, H., Ed.; Kersting-Verlag: Rottenburg am Neckar, Germany, 2008; pp. 175-184, ISBN 3-937559-09-4.

46. Megerle, H. Geoheritage and geotourism in regions with extinct volcanism in Germany; Case study southwest Germany with UNESCO Global Geopark Swabian Alb. Geosciences 2020, 10, 445. [CrossRef]

47. Geyer, M.; Nitsch, E.; Simon, T.; Geyer, O.; Gwinner, M. Geologie von Baden-Württemberg, 5th ed.; E. Schweizerbart'sche Verlagsbuchhandlung: Stuttgart, Germany, 2011; ISBN 978-3510652679.

48. Rothe, P. Die Geologie Deutschlands. 48 Landschaften im Portrait, 5th ed.; Wissenschaftliche Buchgesellschaft: Darmstadt, Germany, 2019; ISBN 978-3534271290.

49. Pfeffer, K.-H. Karst: Entstehung. Phänomene. Nutzung; Bornträger: Stuttgart, Germany, 2010; ISBN 978-3443071479.

50. Golubić, S.; Violante, C.; Plenković-Moraj, A.; Grgasović, T. Travertines and calcareous tufa deposits: An insight into diagenesis. Geol. Croat. 2008, 61, 363-378.

51. Bögli, A. Karsthydrographie und Physische Speläologie; Springer: Heidelberg, Germany, 1978; ISBN 978-3540090151. 
52. Stirn, A. Kalktuffvorkommen und Kalktufftypen der Schwäbischen. Ph.D. Thesis, University Tübingen, Mangold, München, Germany, 1964.

53. Schorn, S. Kalktuff. Available online: https://www.mineralienatlas.de/lexikon/index.php/RockData?rock=Kalktuff (accessed on 13 November 2020).

54. Pentecost, A. Travertine; Springer: Dordrecht, The Netherlands, 2005; ISBN 978-1402035234.

55. Werner, W.; Wittenbrink, J.; Bock, H.; Kimmig, B. Naturwerksteine aus Baden-Württemberg. Vorkommen, Beschaffenheit und Nutzung; Asterion GmbH: Rüsselsheim, Germany, 2013; ISBN 978-3-00-041100-7.

56. Ford, T.; Pedley, H. A review of tufa and travertine deposits of the world. Earth Sci. Rev. 1996, 41, 117-175. [CrossRef]

57. Meschede, M. Geologie Deutschlands Ein Prozessorientierter Ansatz; Springer-Spektrum: Berlin/Heidelberg, Germany, 2015; ISBN 978-3662452974.

58. Zöller, L. Die Physische Geographie Deutschlands; Wissenschaftliche Buchgesellschaft: Darmstadt, Germany, 2017; ISBN 9783534268689.

59. Dramis, F.; Fubelli, G. Tufa Dams in Tigray (Northern Ethiopia) as Late Pleistocene-Holocene Climate Proxies. In Landscapes and Landforms of Ethiopia. World Geomorphological Landscapes; Billi, P., Ed.; Springer: Dordrecht, The Netherlands, 2015. [CrossRef]

60. Pena, J.; Sancho, C.; Lozano, M. Climatic and tectonic significance of late Pleistocene and Holocene tufa deposits in the Mijares river canyon, eastern Iberian Range, northeast Spain. Earth Surf. Proccess. Landf. 2000, 25, 1403-1417. [CrossRef]

61. Dahlhelm, H. Kalktuffhöhlen. Beiträge zur Höhlen- und Karstkunde in Südwestdeutschland; Arbeitsgemeinschaft Höhle und Karst: Stuttgart, Germany, 1982; ISSN 25098993.

62. Gray, M. Geodiversity. Valuing and Conserving Abiotic Nature, 2nd ed.; Wiley-Blackwell: Chennai, India, 2013; ISBN 978-0470742143.

63. Megerle, H. Les cascades de tuf calcaire près de Bad Urach (Allemagne). Valorisation d'un géotope vulnérable du géoparc mondial de l'UNESCO Schwäbische Alb. In Guide Pratique de Valorisation des Géomorphosites; Ambert, M., Cayla, N., Eds.; Presses Universitaires Savoie Mont Blanc: Chambéry, France, 2020; pp. 268-277, ISBN 978-2-37741-046-0.

64. Megerle, H. Cultural values of geomorphosites within the Geopark Swabian Alb. In Gestion des Géosites dans les Espaces Protégés; Hoblea, F., Cayla, N., Reynard, E., Eds.; Collection EDYTEM, 15; Université Savoie Mont Blanc: Chambéry, France, 2014; pp. 149-154.

65. Megerle, H.; Beuter, A. La protection des géotopes et le géotourisme-des intérêts contradictoires ou une préoccupation commune? In Les Géosciences au Service de la Société, Actes du Colloque en L'honneur du Professeur Michel Marthaler; Reynard, E., Laigre, L., Kramar, N., Eds.; Institut de Géographie, Université de Lausanne: Lausanne, Switzerland, 2011; pp. 76-90, ISBN 978-2-940368-12-9.

66. Zhou, X.L. Influences of geological environment deterioration on Jiuzhaigou ravine landscape. Carstologica Sin. 1998, 3, 119-128.

67. Zhang, J.; Wang, H.; Li, D.; Zhao, D. An analysis of travertine landscape degradation in Huanglong Ravine of Sichuan, a world's heritage site, and its causes and protection countermesures. Acta Ecol. Sin. 2012, 1, 111-120.

68. Liu, Z.H.; Tian, Y.P.; An, D.J.; Wang, H.J.; Tang, S.; Zhang, J.L.; Sun, H.; Liu, Y.; Zhang, Q.M. Formation and evolution of the travertine landscape at Huanglong, Sichuan, one of the world natural heritages. Acta Geosci. Sin. 2009, 30, 841-847.

69. BalkanInsight. Available online: https://balkaninsight.com/2017/04/17/uncontrolled-tourism-threatensbalkan-unesco-sites04-13-2017/ (accessed on 28 December 2020).

70. Cappadonia, C.; Coratza, P.; Agnesi, V.; Soldati, M. Malta and Sicily Joined by Geoheritage Enhancement and Geotourism within the Framework of Land Management and Development. Geosci. J. 2018, 8, 253. [CrossRef]

71. Soldati, M.; Buhagiar, S.; Coratza, P.; Magri, O.; Pasuto, A.; Schembri, J.A. Integration of geomorphology and cultural heritage: A key issue for present and future times. Geogr. Fis. Dinam. Quat. 2008, 31, 95-96.

72. Coratza, P.; Gauci, R.; Schembri, J.; Soldati, M.; Tonelli, C. Bridging Natural and Cultural Values of Sites with Outstanding Scenery: Evidence from Gozo, Maltese Islands. Geoheritage 2016, 8, 91-103. [CrossRef]

73. Binder, H. Höhlen der Schwäbischen Alb; DRW-Verlag: Leinfelden-Echterdingen, Germany, 1995; ISBN 3-87181-3966-4.

74. Schreg, R. Hülen und Tuff. Der Mensch und das Wasser auf der Schwäbischen Alb. Heidenheimer Jahrbuch 2010, 13, 28-44.

75. Megerle, H.; Pietsch, D. Geotopschutz als Stiefkind des Naturschutzes. Geoparks im Spannungsfeld von Schutz und Nutzung. Nat. Landsch. 2019, 51, 174-182.

76. European Geoparks Network European Geoparks. Available online: http://www.europeangeoparks.org/ (accessed on 16 September 2020).

77. Geo-Union Alfred Wegener Stiftung Nationaler Geopark. Available online: http://www.nationaler-geopark.de/geopark/ nationale-geoparks/die-16-nationalen-geoparks.html (accessed on 2 October 2020).

78. Deutsche UNESCO-Kommission, e.V.; UNESCO-Geoparks. Vom Geologischen Erbe zu Einer Nachhaltigen Zukunft. Available online: https:/ / www.unesco.de/sites/default/files/2020-06/Geoparks_Imagebroschuere_2020.pdf (accessed on 2 October 2020).

79. Bétard, F. Géodiversité, Biodiversité et Patrimoines Environnementaux: De la Connaissance à la Conservation et à la Valorization; Mémoire d’Habilitation à Diriger des Recherches; Université Sorbonne Paris Cité: Paris, France, 2017.

80. Geopark Teutoburg Forest. Calcerous tufa in Teutoburg Geopark. E-Mail 2020.

81. Hose, T. Geotourism and interpretation. In Geotourism; Dowling, R., Newsome, D., Eds.; Routledge: Amsterdam, The Netherlands, 2006; pp. 221-241, ISBN 978-1906884093.

82. Reynard, E.; Fontana, G.; Kozlik, L.; Scapozza, C. A method for assessing the scientific and additional values of geomorphosites. Geogr. Helv. 2007, 62, 148-158. [CrossRef] 
83. Reynard, E.; Perret, A.; Bussard, J.; Grangier, L.; Martin, S. Integrated Approach for the Inventory and Management of Geomorphological Heritage at the Regional Scale. Geoheritage 2016, 8, 43-60. [CrossRef]

84. Brilha, J. Geoheritage: Inventories and evaluation. In Geoheritage: Assessment, Protection and Management; Reynard, E., Brilha, J., Eds.; Elsevier: Amsterdam, The Netherlands, 2018; pp. 69-86.

85. Brilha, J. Inventory and quantitative assessment of geosites and geodiversity sites: A review. Geoheritage 2016, 8, 119-134. [CrossRef]

86. Feuillet, T.; Sourp, E. Geomorphological heritage of the Pyrenees National Park (France): Assessment, Clustering, and Promotion of Geomorphosites. Geoheritage 2011, 3, 151-162. [CrossRef]

87. Martin-Duque, J.; Caballero Garcia, J.; Carcavilla Urqui, L. Geoheritage Information for Geoconservation and Geotourism through the Categorization of Landforms in a Karstic Landscape. A Case Study from Covalagua and Las Tuerces (Palencia, Spain). Geoheritage 2012, 4, 93-108. [CrossRef]

88. Kiessling, A. Rezente Kalktuffbildung auf der Wiesentalb. Bildungsbedingungen und jahreszeitlicher Verlauf. Mitt. Fränk. Geogr. Ges. 1993, 40, 41-60.

89. Huth, T.; Junker, B. Geotouristische Karte von Baden-Württemberg; LGRB: Freiburg im Breisgau, Germany, 2006; ISBN 978-3000189760.

90. Schedler, J. Die Wasserfälle im Ermstal. In Der Rutschen. Ein Führer durch das Naturschutzgebiet um den Uracher Wasserfall; Dallmann, M., Krahl, W., Muller, T., Nagel, A., Schedler, J., Schiek, S., Schwarz, F., Vetter, E., Eds.; Verlag Regionalkultur: Ubstadt-Weiher, Germany, 1991; pp. 39-67, ISBN 978-3882511598.

91. Deigendesch, R. Die Kartause an den Gütersteiner Wasserfällen. Bl. Schwäb. Albvereins 2003, 2, 4-9.

92. Beuter, A. Einsatz neuer Methoden zur Besucherlenkung im Biosphärengebiet Schwäbische Alb-Am Beispiel des Uracher Wasserfalls. Master's Thesis, University Tübingen, Tübingen, Germany, 2010.

93. Bad Urach Premiumwandern Schwäbische Alb-Grafensteige Bad Urach. Available online: https: / / www.badurach-tourismus. de/Wandern/Premiumwandern-Schwaebische-Alb-Grafensteige-Bad-Urach (accessed on 17 December 2020).

94. Grüninger, W. Rezente Kalktuffbildungen im Bereich der Uracher Wasserfälle; Mangold: München, Germany, 1965.

95. Binder, H. Höhlenführer Schwäbische Alb: Höhlen, Quellen, Wasserfälle; Theiss: Stuttgart, Germany, 1989; ISBN 3-8062-0499-3.

96. Waßner. M. Ein langes, dunkles Bauwerk-Heinrich Schickhardts "Seedohle" In Bodenloser See und Schickhardt-Stollen; Rosendahl, W., Sahm-Stotz, D., Eds.; Grabenstätter Höhlenkundliche Hefte 10; Göckel Druck und Graphik GmbH: Burladingen, Germany, 2005; pp. 33-37, ISBN 3-929981-57-2.

97. Blank-Mathieu, M. Der Tuffsteinabbau in Gönningen. Reutl. Geschichtsbl. 2012, 51, 231-265.

98. Frank, M. Die Natürlichen Bausteine und Gesteinsbaustoffe Württembergs; Schweizerbart: Stuttgart, Germany, 1944; ISBN 978-3-51099023-8.

99. Ziegler, M. Honau und die Olgahöhle. Abh. Karst Höhlenkd. 1998, 7, 3-26.

100. Huth, T. Erlebnis Geologie. Streifzüge über und unter Tage. Besucherbergwerke, Höhlen, Museum und Lehrpfade in Baden-Württemberg; LGRB: Freiburg im Breisgau, Germany, 2002; ISBN 978-3000095665.

101. Huth, T.; Junker, B. Geotouristische Karte Nationaler Geopark Schwäbische Alb mit Umgebung; Reiff Druck: Munich, Germany, 2003.

102. Megerle, H.; Schrembs, R. Ökonomische Effekte in den europäischen Nationalen Naturlandschaften-Beiträge der Geoparke und des Geotourismus für eine nachhaltige Regionalentwicklung. Thüringer Ministerium für Landwirtschaft, Naturschutz und Umwelt, Ed.; Weltnaturerbe Buchenwälder: Saalfeld, Germany, 2009; pp. 247-257.

103. Megerle, H.; Pietsch, D. Consequences of overlapping territories between large scale protection areas and Geoparks in Germany: Opportunities and risks for geoheritage and geotourism. Ann. Géographie 2017, 717, 598-624. [CrossRef]

104. Bundesamt für Naturschutz Arbeitsanleitung Geotopschutz in Deutschland; Landwirtschaftsverlag: Münster, Germany, 1996; ISBN 9783896243065.

105. Clement, T. Personal reference about Corona Pandemic and its consequences for Urach Waterfall. January, 2021.

106. Luo, Y.; Deng, J. The New Environmental Paradigm and Nature-Based Tourism Motivation. J. Travel Res. 2008, 46, 392-402. [CrossRef]

107. De Oliveira, A.; Santos, G.; Santos Lobo, H. Environmental Attitudes and Tourist Satisfaction in Overloaded Natural Protected Areas. J. Travel Res. 2020. [CrossRef]

108. Bachinger, M.; Pohl, N.; Welk, L. Die Bedeutung von Wasser für die Landschaftswahrnehmung von Erholungssuchenden. Ergebnisse einer Befragung am Uracher Wasserfall. In Ressourcenmanagement Wasser. Aktuelle Bedeutung, Trends und Herausforderungen; Megerle, H., Ed.; Geographie in Wissenschaft und Praxis, 5, Kersting-Verlag: Rottenburg/Neckar, Germany, 2019; pp. 275-310, ISBN 978-3-00-063859-6.

109. INDECON An Economic Review of the Irish Geoscience Sector. Available online: https://www.leisuresolutions.com.au/wpcontent/uploads/2015/02/Indecon_Economic_Review_of_Irish_Geoscience_Sector_Nov2017.pdf (accessed on 5 October 2020).

110. Waitt, G.; Lane, R.; Head, L. The Boundaries of Nature Tourism. Ann. Tour. Res. 2003, 30, 523-545. [CrossRef]

111. Giusti, C. Introduction to the thematic issue: "From Geosites to Geomorphosites: How to decode the landscape? Geodynamic processes, surficial features and landforms, past and present environments". Géomorphologie 2010, 2, 123-130. [CrossRef]

112. Reynard, E.; Panizza, M. Géomorphosites: Definition, evaluation et cartographie. Une introduction. Géomorphologie 2005, 3 , 177-180. [CrossRef] 